\title{
COMMENT
}

\section{THE STATE ACTION EXEMPTION IN ANTITRUST: FROM PARKER V. BROWN TO CANTOR V. DETROIT EDISON CO.}

In Parker v. Brown, ${ }^{1}$ the Supreme Court held that the Sherman Act did not prohibit restraints on commerce imposed by a state acting as sovereign. It thus apparently resolved the potential conflict between the expanding scope of the Act under the commerce clause and state regulation of intrastate commerce. In establishing this state action exemption, however, the Court indicated that certain acts by the state would not be immune from the federal antitrust laws. As the lower courts attempted to apply the Parker holding, they encountered difficulty in determining whether the challenged activity constituted state action and, if so, whether it fell within one or two exceptions to state action immunity noted by the Parker Court.

In applying the state action exemption, the courts typically looked for factors present in Parker, primarily, state intent to restrict competition and the degree of state involvement in the activity in terms of implementation, supervision or control. Although the emphasis given particular factors and the results reached were inconsistent, the courts generally limited the potential reach of Parker by allowing the exemption only when the challenged activity reflected a conscious state policy. The Supreme Court decision in Goldfarb v. Virginia State Bar ${ }^{2}$ confirmed this trend, since the standard it enunciated - that the activity must be required by the stateappeared even stricter than those previously imposed in the lower courts. The significance of the Goldfarb test was unclear, however, since the Court mentioned additional factors which may have formed the basis for its decision. $^{3}$

Cantor v. Detroit Edison Co. ${ }^{4}$ presented the Court with a situation to which the Parker doctrine has been frequently applied and which satisfied

THE FOLLOWING CITATION WILL BE USED IN THIS COMMENT:

Slater, Antitrust and Government Action: A Formula for Narrowing Parker v. Brown, 69 Nw. U.L. REv. 71 (1974) [hereinafter cited as Slater].

1. 317 U.S. 341 (1943).

2. 421 U.S. 773 (1975).

3. See notes $44-49,61$ infra and accompanying text.

4. 428 U.S. 579 (1976). 
the Goldfarb standard in at least a literal sense. ${ }^{5}$ The case thus offered the Court an excellent opportunity to clarify the Goldfarb decision and to establish the appropriate standards to be used in applying the Parker exemption. Although the Court's conclusion that the challenged activity was not protected from the operation of the Sherman Act was not surprising in light of the minimal degree of state involvement, the reasoning of the plurality, particularly in its emphasis on the identity of the parties involved in the suit rather than the challenged anticompetitive activity, perpetuated the ambiguity of Goldfarb and further complicated the already difficult task of applying Parker. In order to gauge the impact of Cantor, this Comment will first examine the formulation of the Parker exemption and its application by the courts prior to Cantor. ${ }^{6}$ It will then analyze the Cantor decision, emphasizing its further complication of the state action inquiry.

\section{THE PARKER V. BROWN DECISION}

When Congress passed the Sherman $\mathrm{Act}^{7}$ in 1890 it contemplated a complementary relationship between the federal law and pre-existing state statutes aimed at preventing or controlling monopolies or combinations in restraint of trade. ${ }^{8}$ Though Congress intended to exercise all the power it possessed, ${ }^{9}$ the narrow scope of its power under the commerce clause as then interpreted ${ }^{10}$ did not permit the invasion of a state's authority to regulate commerce within its borders. As the Supreme Court began to recognize an expanded commerce clause power, allowing Congress to regulate intrastate activities if they had a significant impact on interstate commerce, ${ }^{11}$ the scope of the Sherman Act was also expanded. ${ }^{12}$ Conse-

5. Cantor involved a public utility rate schedule which the utility was required to follow until a new one was adopted.

6. The Court has recently applied the Parker doctrine to a state supreme court's prohibition of attorney advertising. Bates v. State Bar of Arizona, 97 S.Ct. 2691 (1977). The Court distinguished Cantor on several grounds, but did not examine that decision in any detail. See note 162 infra.

7. 15 U.S.C. $\S \S 1-7$ (1970).

8. No attempt is made to invade the legislative authority of the several States or even to occupy doubtful grounds. No system of laws can be devised by Congress alone which would effectively protect the people of the United States against the evils and oppression of the trusts and monopolies. Congress has no authority to deal, generally, with the subject within the States, and the States have no authority to legislate in respect of commerce between the several States or with foreign nations. It follows, therefore, that the legislative authority of Congress and that of the several States must be exerted to secure the suppression of restraints upon trade and monopolies. Whatever legislation Congress may enact on this subject, within the limits of its authority, will prove of little value unless the States shall supplement it by such auxiliary and proper legislation as may be within their legislative authority.

H.R. ReP. No. 1707, 51 st Cong., 1st Sess. 1 (1890).

9. 20 CONG. REC. 1167 (1889).

10. Cantor, 428 U.S. at 632 (Stewart, J., joined by Powell \& Rehnquist, J.J., dissenting); Slater 84. See, e.g., Kidd v. Pearson, 128 U.S. 1, 20 (1888).

11. In NLRB v. Jones \& Laughlin Steel Corp., 301 U.S. 1, 37 (1937), the Court stated: 
quently, state regulation of commerce which would have been considered domestic in 1890 might today be subject to federal preemption under the commerce clause and fall within the scope of the Sherman Act.

The Court first faced this potential conflict in Olsen $v$. Smith, ${ }^{13}$ rejecting the contention that a Texas law, which in effect granted state commissioned pilots a monopoly of the pilotage business in the port of Galveston, was repugnant to the federal antitrust laws. ${ }^{14}$ The implications of Olsen were developed into an express exemption in Parker. Emphasizing the legislative history of the Sherman Act, the Parker Court held that a restraint on commerce imposed by a state acting as sovereign was not prohibited by the Sherman Act. ${ }^{15}$

Parker involved a challenge to a California program regulating the marketing of raisins pursuant to the California Agricultural Prorate Act, ${ }^{16}$ the purpose of which, was "to restrict competition among the growers and maintain prices in the distribution of their commodities to packers." 17 The Act authorized the creation of an Agricultural Prorate Advisory Commis$\operatorname{sion}^{18}$ which had power to grant petitions by producers for the establishment of a prorate marketing zone, to appoint a committee to formulate a marketing program for that commodity, to modify any suggested program and to

\footnotetext{
Although activities may be intrastate in character when separately considered, if they have such a close and substantial relation to interstate commerce that their control is essential or appropriate to protect that commerce from burdens and obstructions, Congress cannot be denied the power to exercise that control.

12. Hospital Bldg. Co. v. Rex Hosp. Trustees, 425 U.S. 738,743 n.2 (1976).

13. I95 U.S. 332 (1904).

14. Id. at 344-45. The language of the Court in Olsen strongly implied that though such a monopoly by private persons might violate the antitrust laws, when it resulted from state regulation it did not:

The contention that because the commissioned pilots have a monopoly of the business, and by combination among themselves exclude all others from rendering pilotage services, is also but a denial of the authority of the State to regulate, since if the State has the power to regulate, and in so doing to appoint and commission those who are to perform pilotage services, it must follow that no monopoly or combination in a legal sense can arise from the fact that the duly authorized agents of the State are alone allowed to perform the duties devolving upon them by law. Id.

15. 317 U.S. at 352

16. Act of June 5, 1933, ch. 754, 1933 Cal. Stats. 1969, as amended by chs. 603,1150 \& 1186, 1941 Cal. Stats. 2050, 2858 \& 2943; chs. 363, 548 \& 894, 1939 Cal. Stats. 1702, 1947 \& 2485 ; ch. 6, 1938 Cal. Stats. Extra Sess. 39; \& chs. 471 \& 473, 1935 Cal. Stats. 1526 \& 2087. The current provisions of the Act are embodied in the Agricultural Producers Marketing Law, CAL. AGRIC. CODE $\S \S 59501-60015$ (West 1968).

17. 317 U.S. at 346.

18. The Commission was composed of state officials with the Director of Agriculture serving ex officio. The Act, however, provided for participation by the producers. Before granting a petition or approving a plan the Commission was required to hold public hearings. An approved plan could not become effective without the consent of $65 \%$ of the producers in a zone who owned $51 \%$ of the acreage devoted to production of the crop being regulated. Thereafter, the program was administered by the Director of Agriculture, and penalties for noncompliance were prescribed. Id. at 346-47.
} 
give final approval after determining that a program would promote the objectives of the Act without permitting unreasonable profits. ${ }^{19}$

Under one marketing program, producers had to deliver all raisins they wished to market to stations where the raisins were graded. The producer was then permitted to sell less than one-third of his standard raisins through ordinary commercial channels after obtaining a certificate designed to control "the time and volume of movement" of such "free-tonnage" raisins. ${ }^{20}$ One-half of the standard raisins were placed in a stabilization pool to be disposed of "in such manner so as to obtain stability in the market and to dispose of such raisins," 21 though never at less than the prevailing market price. The remainder of the standard raisins were placed into a surplus pool with the lower grade raisins. The producers were advanced fixed prices per ton for raisins delivered into the pools.

Despite these severe restrictions on the producers' ability to market their raisins, the Court upheld the program. The Court explained that the prorate scheme was not prohibited by the Sherman Act because, unlike "a contract, combination or conspiracy of private persons," 22 it "derived its authority and its efficacy from the legislative command of the state." 23

In reaching the decision that the Sherman Act does not prohibit state action, the Court assumed that Congress could prohibit a state from maintaining a program like the California prorate program under the commerce clause. The Court noted, however, that considerations of federalism weighed against lightly attributing "an unexpressed purpose to nullify a state's control over its officers and agents." 24 Nowhere in the Sherman Act is a state as such mentioned. Though the Court had only recently permitted a state to sue for damages under the Sherman Act, ${ }^{25}$ that interpretation was based on "the purpose, the subject matter, the context and the legislative history of the statute." 26 In Parker, similar inquiry into the legislative history led to the conclusion that the statute was directed, not at "state action or official action directed by a state," but at "combinations to restrain competition and attempts to monopolize by individuals and corporations." 27

19. The broad objectives of the Act were "to conserve the agricultural wealth of the State" and "to prevent economic waste in the marketing of agricultural products" of the state. Id. at 346.

20. Id. at 348.

21. Id.

22. Id. at 350 .

23. Id.

24. Id. at 351.

25. Georgia v. Evans, 316 U.S. 159 (1942).

26. 317 U.S. at 351.

27. Id. 
In the Court's view, the California prorate program clearly constituted state action. The state created the machinery for establishing the program, approved it through the Commission, adopted and enforced it in the execution of a governmental policy. ${ }^{28}$ The Court noted, however, that certain types of state action might not be excepted from the operation of the Sherman Act: first, an authorization to private individuals to violate the Sherman Act or a declaration that their action was lawful, ${ }^{29}$ and second, state participation in a private agreement or combination by others for restraint of trade. ${ }^{30}$

The casual manner in which the Court noted these exceptions and its brief discussion of them suggests that they were intended to cover clearly defined situations: when the state attempted to circumvent the operation of the Sherman Act within its borders or when the state acted other than as sovereign. ${ }^{31}$ Subsequent attempts to delineate the boundaries of the Parker exceptions, however, have produced a "quagmire"32 of legal reasoning.

\section{BETWEEN PARKER AND CANTOR: THE QUAGMIRE}

The holding in Parker, combined with the sweeping language of the Court, established the general proposition that state government action is not subject to the prohibitions of the Sherman Act-a doctrine that is commonly known as the state action exemption. ${ }^{33}$ If the existence of the exemption was

28. Id. at 352 .

29. Id. at 351. The Court cited Northern Sec. Co. v. United States, 193 U.S. 197 (1904) as support for this proposition, which seems almost self-evident in light of the supremacy clause.

30. 317 U.S. at 351-52. Though nominally state action, such government activity is private and proprietary in nature. The state has thus abdicated its position as sovereign and subjected itself to Sherman Act liability. This distinction seems borne out in the Court's conclusion:

The state in adopting and enforcing the prorate program made no contract or agreement and entered into no conspiracy in restraint of trade or to establish monopoly but, as sovereign, imposed the restraint as an act of government which the Sherman Id. at 352 .

Act did not undertake to prohibit.

31. The latter situation would simply require that a court make the distinction between governmental and proprietary action as made, for example, in the torts area. See W. PROSSER, HANDBOOK OF THE LAW OF TORTS $§ 131$, at 977-84 (4th ed. 1971).

32. Costilo, Antitrust's Newest Quagmire: The Noerr-Pennington Defense, $66 \mathrm{MicH}$. L. REv. 333 (1967); Note, The Quagmire Thickens: A Post-California Motor View of the Antitrust and Constitutional Ramifications of Petitioning the Government, 42 U. CINN. L. REV. 281 (1973).

33. This label has been criticized as misleading. Slater has described the use of the term as somewhat unfortunate, since

[t]echnically, no doctrine of exemption was necessary for the ruling in Parker $v$. Brown, ... [T]he rationale was simply that the federal antitrust laws do not and were not intended by Congress to apply to conduct sanctioned by the state governments. The Parker decision is therefore one of non-applicability. To term the doctrine as one of "exemption" is really a misnomer since conduct which does not violate an act hardly needs to be exempted from its application.

Slater 71 n.4. See Duke \& Co. v. Foerster, 521 F.2d 1277, 1279 n.5 (3d Cir. 1975). 
clear, its precise limits were not. The infrequent Supreme Court cases which referred to Parker before the Court reexamined the issue in 1976 in Cantor did little to clarify either the guidelines to be followed in its application or the underlying rationale. ${ }^{34}$ In attempting to apply Parker, the lower courts encountered two difficult questions: whether a challenged activity constituted state action and, if so, whether it fell within one of the exceptions. The frequent failure of the courts to distinguish between the two inquiries made it difficult to predict and interpret decisions. Faced with fact situations different from that in Parker, the courts developed various tests for finding state action which often produced inconsistent results. Instead of offering guidance, the expressed rationale of Parker-that the Sherman Act was not intended to reach state action-raised additional questions in light of the expansion of the commerce clause power. ${ }^{35}$ The variety of tests and results seemed to reflect particular courts' attitudes toward the continuing validity of Parker $^{36}$ or the challenged activity itself. ${ }^{37}$

\section{A. The First Inquiry: Whether a Challenged Activity Constitutes State Action}

The program held exempt as state action in Parker was adopted by a state commission established pursuant to a statute with the expressed pur-

34. Most of the cases before Cantor that referred to Parker cited it for its discussion of the commerce clause issue and not of the Sherman Act. See, e.g., Pike v. Bruce Church, Inc., 397 U.S. 137 (1970); H.P. Hood \& Sons, Inc. v. DuMond, 336 U.S. 525 (1949).

35. Slater 84-86. Slater suggests that given the changed interpretation of the scope of the commerce clause by 1942, "the rational approach ... . would therefore have been . . . to inquire whether Congress at that time would have wanted the supremacy clause to override state action which violated the spirit of our antitrust laws, and if so to what extent." Id. 85-86.

36. See, e.g. , Hecht v. Pro-Football, Inc., 444 F.2d 931 (D.C. Cir. 1971), cert. denied, 404 U.S. 1047 (1972); see notes 72-76 infra and accompanying text. The Hecht court indicated that it was the overly broad language of Parker which had provided the basis for a much more expansive governmental action immunity doctrine in later cases and "opened the eyes of the antitrust bar to the possibilities of avoiding the impact of the antitrust laws, if only state governmental action is in some way involved." 444 F.2d at 936. In light of the importance of the federal antitrust laws, the court rejected as "too talismanic," id. at 934, the general statement that the antitrust laws do not apply when unequivocal state action can be established. Id. at 938 . It then used a balancing test to reject antitrust immunity for the action of the District of Columbia Armory Board which prohibited any professional football team other than the Washington Redskins from using Kennedy Stadium during the term of the Redskins' lease. See notes 142-45 infra and accompanying text.

37. In Woods Exploration \& Producing Co. v. Aluminum Co. of America, 438 F.2d 1286 (5th Cir. 1971), cert. denied, 404 U.S. 1047 (1972), where a gas production formula based on false figures had been set by the Railroad Commission, the court's desire not to find state action was obvious in its narrow construction of the state action exemption. The court indicated: "[I]t is not every governmental act that points a path to an antitrust shelter. . . . Each case must be considered on its own facts in order to determine whether or not the anticompetitive consequence is truly the action of the state." 438 F.2d at 1294 (emphasis added). The court then found no state action on the ground that the Commission would not have intended the consequences of its action. Id. at 1295. See notes 51-55 infra and accompanying text. 
pose of restricting competition and maintaining prices. Accordingly, many courts have attempted to base findings of state action on the presence of similar elements: an expressed intent by the state to restrict competition, or state involvement in the activity through implementation, supervision, control or compulsion. ${ }^{38}$ The emphasis the courts have placed on these factors, however, has not been consistent.

1. Intent. In Parker the Court found that the California legislature intended, through the challenged program, to restrict competition among raisin producers and maintain the prices at which raisins were sold to packers. ${ }^{39}$ Some courts have held that clearly expressed intent to implement a state policy through anticompetitive measures is necessary for application of the Parker doctrine, but again, not all agree.

38. The situation in Parker also involved a federal statute which, though not expressly providing for state programs such as the one challenged, seemed to contemplate them. See 317 U.S. at 354 (discussing the Agriculture Marketing Agreement Act of 1937, 50 Stat. 246 (codified in scattered sections of 7 U.S.C. (1970)). The Parker Court found the California program to be consistent with the purposes of the federal act, 317 U.S. at 354-58, but did not use that factor in its resolution of the Sherman Act issue. It has been suggested, nevertheless, that such a federal "enabling statute" should be required for an exemption of state action from the antitrust laws. Note, State Action Exemption From the Antitrust Laws, 50 B.U.L. REv. 393, 400 (1970).

39. 317 U.S. at 346 . These specific goals were designed to effectuate the underlying policy of conserving the state's agricultural wealth and preventing waste in marketing agricultural products. Id. The Sherman Act has also been interpreted as having two levels of objectives: a basic goal- "to achieve the most efficient allocation of resources possible"-and the more specific goals enumerated in the Act itself, which are a form of indirect governmental regulation to achieve the basic goal. Northern Natural Gas Co. v. Federal Power Commission, 399 F.2d 953 (D.C. Cir. 1968). The District of Columbia Circuit indicated direct government regulation could be used to achieve the same basic goals. Id. Several commentators have suggested that regulation need not be inconsistent with the underlying goals of the antitrust laws, which, when so broadly defined, seem coextensive with the public interest. See Handler, Regulation Versus Competition, 43 A.B.A. ANTITRuST L.J. 277, 289-91 (1974) (suggesting Congress, not the courts, must decide whether competition or regulation best advances the public interest in a particular situation); Kauper, An Overview, 43 A.B.A. ANTITRUST L.J. 295 (1974). See also Note, Parker v. Brown: A Preemption Analysis, 84 YALE L.J. 1164, 1170-71 (1975) (state should be able to choose among antitrust goals of preservation of small competitors and preservation of competition to insure allocative efficiency and adequate quality at a fair price if both cannot be realized).

The distinction between the two goals of the Sherman Act may have underlain the Parker Court's statement that states cannot authorize violations of the Sherman Act, see notes 107-08 infra and accompanying text, if such were designed to circumvent both goals. If the Parker holding that states can authorize anticompetitive conduct were read to apply only if the underlying goal was not thereby circumvented, an apparent inconsistency between the holding and the exception would be avoided. Such a reading of Parker would allow the courts to reach anticompetitive legislation designed for special interest groups, not the general public good, for example, licensing barbers. One commentator proposes a primary jurisdiction approach for such situations which would allow the courts to intervene if there were no expressed intent to administer competition and insufficient procedural protections. Verkuil, State Action, Due Process and Antitrust: Reflections on Parker v. Brown, 75 CoLuM. L. REv. 328, 340-50 (1975).

In the context of professional regulation, the Ninth Circuit has interpreted Goldfarb and Cantor as standing for the proposition that: 
In George R. Whitten, Jr., Inc. v. Paddock Pool Builders, Inc. ${ }^{40}$ such intent was deemed to be a sine qua non if an activity was to qualify for exemption from the antitrust laws. The court stated that antitrust immunity was available only when the state government determines that competition is not desirable in a particular field and deliberately attempts to provide an alternate form of public regulation..$^{41}$ In instances where state policy was neutral or silent with respect to restraints of trade, or was procompetitive, Parker would be inapplicable. In Whitten, a local official had adopted specifications for public swimming pools on the urging of a builder and dealers who had drawn the specifications so that only they could comply, thus effectively eliminating competition for contracts to build pools. The court determined, however, that in requiring competitive bidding for government contracts, the state had expressed an intent "to respond to the signals of a competitive market," 42 thus indicating a procompetitive state policy. The effects of the local official's action were therefore contrary to state intent and his adoption of the specifications was accordingly held insufficient to confer antitrust immunity on the builder. ${ }^{43}$

The Supreme Court in Goldfarb v. Virginia State Bar ${ }^{44}$ also emphasized intent in rejecting a claim of state action. ${ }^{45}$ Goldfarb involved a

To survive a Sherman Act challenge a particular practice, rule, or regulation of a profession, whether rooted in tradition or the pronouncements of its organizations, must serve the purpose for which the profession exists, viz. to serve the public. That is, it must contribute directly to improving service to the public. Those which only suppress competition between practitioners will fail to survive the challenge.

Boddicker v. Arizona State Dental Ass'n, 549 F.2d 626, 632 (9th Cir. 1977).

40. 424 F.2d 25 (1st Cir.), cert. denied, 400 U.S. 850 (1970).

41. 424 F.2d at 30.

42. Id. at 31 .

43. Id. The court noted that though the action was "in form governmental," the real decisionmakers were private businessmen and their activities were not protected by Parker. Id. at 30 .

44. 421 U.S. 773 (1975).

45. The Court based its finding of no state action on several factors including the intent of the state supreme court, the nature of the state bar, see notes $49 \& 61$ infra and accompanying text, and the fact that the challenged action was not required by the state. The Court did not specify the relative importance of the factors it considered and indicated that a finding that the activity was required by the state would only satisfy the threshold inquiry as to whether Parker would apply, thus leaving doubt as to the exact standards to be employed. See Surety Title Ins. Agency, Inc. v. Virginia State Bar, 431 F. Supp. 298, 305 (E.D. Va. 1977); Note, The State Action Exemption and Antitrust Enforcement Under the Federal Trade Commission Act, 89 HARV. L. REV. 715, 726 (1976); see notes 150-51 infra and accompanying text.

At least one court has interpreted Goldfarb as establishing that "absent state authority which demonstrates that it is the intent of the state to restrain competition in a given area, Parker-type immunity or exemption may not be extended to anti-competitive government activities." Duke \& Co. v. Foerster, 521 F.2d 1277, 1280 (3d Cir. 1975). The Third Circuit then noted that such intent could be demonstrated either by explicit language in state statutes or could be inferred from the powers and duties granted to a particular entity. Id. See notes 61-81 infra and accompanying text. 
challenge to minimum fee schedules adopted by state and county bar associations and enforced by possible disciplinary action for repeated violations. ${ }^{46}$ The Court found that "far from exercising state power to authorize binding price fixing, [the Virginia Supreme Court had] explicitly directed lawyers not 'to be controlled' by fee schedules." 47 The Virginia Supreme Court had suggested that attorneys refer to fee schedules for guidance in establishing their fees. Therefore, the adoption by the bar associations of mandatory minimum fee schedules was not required by the state supreme court and was also contrary to that court's intent. The fee schedules thus were not exempt from the antitrust laws. ${ }^{48}$

The Supreme Court in Goldfarb avoided any potential conflict between the state's intent as expressed by the state supreme court and the intent of the bar association by construing the latter as a private organization, at least with respect to the fee schedules. ${ }^{49}$ The First Circuit in Whitten did not discuss the official's intent, perhaps assuming that any actions contrary to the desires of the state were outside the scope of his authority. The court also implied that his position was not important enough to allow his intent to be attributed to the state. ${ }^{50}$

While express state intent to limit competition has thus been considered dispositive by some courts in determining that an activity is exempt from the Sherman Act, an express provision limiting competition has not always led to automatic immunity. In Woods Exploration \& Producing Co. v. Aluminum Co. of America, ${ }^{51}$ the Fifth Circuit relied on an implied contrary intent to preclude a finding of state action. The Texas Railroad Commission was empowered by statute to restrict competition among well producers in order to prevent waste through overproduction of natural gas. In setting the proration formula, the Commission looked to market forecasts supplied by

The Court assumed in Goldfarb, without discussion, the continuing validity of the state action exemption.

46. 421 U.S. at 791 n.21.

47. Id. at 789.

48. Id. at $789-91$.

49. See note 61 infra and accompanying text. The Court relied on the fact that the state bar association was a state agency only for the purpose of acting as an administrative agency of the court to implement its rules and regulations. VA. CODE $\$ 54-49$ (1974). Cf. Bates v. State Bar of Arizona, 97 S.Ct. 2691, 2697 (1977) (state bar acted as agent of state supreme court in enforcing disciplinary rule banning attorney advertising).

50. In discussing the possible application of the Noerr-Pennington doctrine, see note 134 infra, the court noted:

The entire thrust of Noerr is aimed at insuring uninhibited access to government policy makers .... [T] he efforts of an industry leader to impose his product specifications by guile, falsity, and threats on a harried architect hired by a local school board hardly rise to the dignity of an effort to influence the passage or enforcement of laws.

424 F.2d at 32.

51. 438 F.2d 1286 (5th Cir. 1971), cert. denied, 404 U.S. 1047 (1972). 
the large producers. ${ }^{52}$ Because of false production forecasts filed by the large producers, the formula adopted had a disproportionate effect on small producers. Despite the existence of an express statutory intent of the state to restrict competition and the fact that the Commission was clearly a state agency for purposes of adopting such proration formulas, the court held that no state action was present because the Commission had not intended the specific anticompetitive results. ${ }^{53}$

Although the deliberate attempt by the large producers to subvert the administrative decisionmaking process and the lack of meaningful supervision of the preparation of the forecasts or verification of them by the Commission may justify the result in Woods, the court's approach creates analytical difficulties. While purporting to find no state action, the court actually determined that this particular kind of state action should not be protected by Parker ${ }^{54}$ even though the state had expressly determined that free competition would not be in the best interest of its citizens. ${ }^{55}$ The jurisdictional approach established in Parker, however, does not permit the Sherman Act to reach state activities simply because a court deems those activities unwise. ${ }^{56}$ Nevertheless, the language of the Woods court has served as a basis for other decisions limiting the scope of Parker. ${ }^{57}$

52. The Commission could, however, modify any figures it considered inaccurate. $438 \mathrm{~F} .2 \mathrm{~d}$ at 1292.

53. "Hence defendants' conduct here can in no way be said to have become merged with the action of the state since the Commission neither was the real decision maker nor would have intended its order to be based on false facts." Id. at 1295.

54. "[I]t is not every governmental act that points a path to an antitrust shelter." Id. at 1294. See Slater 97-101. Slater interprets Woods as standing for the proposition that "state action which is so ill-advised as to serve no state purpose will be insufficient to invoke a Parker exemption." Id. 97. The Commission's action constituted such action since it produced no public benefit to balance against the injury to competition. Slater believes this exception to Parker immunity is limited to cases involving "easily demonstrated factual error or administrative ineptitude." Id. 103.

55. In Cantor the Supreme Court attempted to avoid this dilemma by holding Parker inapplicable to actions by private parties unless the states' participation were sufficient to make such a holding unfair. See notes 169-78 infra and accompanying text. This reading of Parker rested on a distinction largely ignored in Parker and subsequent cases and failed to reach the underlying question of whether the jurisdictional approach is desirable.

56. The Parker decision was based on concern for principles of federalism and the determination "that Congress had left the states some power to regulate their own economic activities and that the judiciary should not undertake to plug the gap that the legislature had left open." Note, Of Raisins and Mushrooms: Applying the Parker Antitrust Exemption, 58 VA. L. REv. 1511,1514 (1972). Accordingly, Parker and the demise of substantive due process require that, though there may be little economic justification for the anticompetitive scheme and its desirability may be open to question, "when confronted with a potential conflict between regulatory and antitrust statutes, the courts cannot legitimately opt for what they consider to be the wiser of the alternatives." Id. 1512. See generally Verkuil, supra note 39.

57. See, e.g., Hecht v. Pro-Football, Inc., 444 F.2d 931 (D.C. Cir. 1971), cert. denied, 404 U.S. 1047 (1972). 
The better approach, and one consistent with the Supreme Court's language in Parker, is illustrated in Ladue Local Lines, Inc. v. Bi-State Development Agency. ${ }^{58}$ In contrast with Woods, Ladue held that the activity of a bi-state agency establishing a monopoly in public bus transportation in St. Louis was exempt. The court emphasized the importance of the states' determination that it was in the public interest to establish such a monopoly, stating that if there exists an explicit public policy against free competition in an essential industry, "state control and regulation of that industry, even to the extent of eliminating competition, is permissible." 59 Since the activity challenged was conducted pursuant to legislative authorization ${ }^{60}$ and the anticompetitive effects were anticipated by the legislatures, the court had little difficulty in finding state action protected by Parker.

In most cases, however, the intent of the state is not as clear as in Ladue. Where the challenged activity is that of a statutorily established entity, the court must determine if the entity's intent can be attributed to the state. Such inquiry has tended to turn on the scope of the entity's authority. Once again, however, the courts have established no consistent tests to determine when a state agency is acting outside the scope of its authority.

In Goldfarb, the promulgation of minimum fee schedules by the state bar association was held not to constitute state action since the bar association was a state agency only for limited purposes, none of which included fostering "anticompetitive practices for the benefit of its members." 61 Similarly, in Asheville Tobacco Board of Trade, Inc. v. FTC, ${ }^{62}$ the Fourth Circuit held that the anticompetitive actions of a local tobacco board could not be attributed to the state. Though the state intended local tobacco boards to make reasonable regulations for the sale of leaf tobacco at auction in order to achieve economical and efficient handling, ${ }^{63}$ the court determined that such intent did not include price fixing or making regulations in restraint of trade. ${ }^{64}$ Since the court concluded that the tobacco board was not a public agency, ${ }^{65}$ it looked only to the statute granting the board regulatory powers

58. 433 F.2d 131 (8th Cir. 1970).

59. Id. at 137 .

60. Id. at 133.

61. 421 U.S. at 791. See note 45 supra. By statute, the state bar association acted as an administrative agency of the [Virginia Supreme] Court for the purpose of investigating and reporting the violation of such rules and regulations as are adopted by the Court under this article . . . and requiring all persons practicing law in this State to be members thereof in good standing.

VA. CODE § 54-49 (1974).

62. 263 F.2d 502 (4th Cir. 1959).

63. N.C. GEN. STAT. $\$ 106-465$ (1975).

64. 263 F.2d at 505 .

65. The court noted several factors that influenced its decision that the tobacco board was not a public agency: the board was organized primarily for the benefit of those engaged in the business; its rules and regulations were enforced by consent of the members to the articles of association; the state bore no part of the expense; the officers and directors were not elected or 
and not to the actions of the board itself. Thus, both Goldfarb and Asheville Tobacco adopt the view that an entity granted regulatory powers by statute does not act within the scope of its authority if its activities impose a restraint on trade without express authorization. ${ }^{66}$ Accordingly, such activities are not exempt from the antitrust laws.

In contrast, in E.W. Wiggins Airways, Inc. v. Massachusetts Port Authority ${ }^{67}$ the First Circuit upheld as state action the decision of the Port Authority to grant one firm the exclusive right to conduct fixed base operations at the municipal airport. It noted that the Port Authority was by statute a public instrumentality exercising its powers in the performance of an essentially governmental function and operating solely for the benefit of the public. ${ }^{68}$ There was no indication that in establishing the Port Authority the legislature had contemplated that it would engage in or authorize anticompetitive activity, yet the First Circuit attributed to the state the Port Authority's decision to end competition among fixed base operators at the airport.

These decisions might be distinguished by the differences in the nature of the entities involved. The Port Authority in Wiggins was considered a public agency, exercising many powers possessed only by governmental entities. ${ }^{69}$ The tobacco board in Asheville Tobacco, however, was not considered a purely public agency, ${ }^{70}$ even though it was granted specific regulatory powers by the state legislature. ${ }^{71}$

appointed by the state; the officers and directors were not accountable to the state; and the board was not required to comply with statutory requirements for state agencies. 263 F.2d at 509-10. One commentator has suggested that though the board's action was state action it did not qualify for the Parker exemption because the final decision was made not by an independent state official but by a group of individuals whose interests were potentially conflicting with the public interest and the interests of those regulated. Slater 92-94.

66. The Goldfarb Court did leave open the question as to whether approval of the minimum fee schedules by the state supreme court would have been sufficient to evoke Parker protection. 421 U.S. at 791. See Robinson, Recent Antitrust Developments: 1975, 76 COLUM. L. REV. $191,195 \mathrm{n} .32,211$ (1976). It has been suggested that the state intention to supplant competition with regulation should be made clear through express statutory authorization of the agency's use of anticompetitive measures. See Note, supra note 56, at 1522.

67. 362 F.2d 52 (1st Cir.), cert. denied, 385 U.S. 947 (1966).

68. $362 \mathrm{~F} .2 \mathrm{~d}$ at 55 .

69. Id. However, in Duke \& Co. v. Foerster, 521 F.2d 1277 (3d Cir. 1975), immunity was denied municipal corporations whose authority to manage public facilities was not considered to include the right to discriminate against certain suppliers. See note 73 infra.

70. See note 65 supra.

71. It may also be significant that the Supreme Court in Goldfarb, 421 U.S. at 791, and the Fourth Circuit in Asheville Tobacco, 263 F.2d at 509, felt that the challenged anticompetitive activities were designed to benefit the members of the entities adopting them, whereas in Wiggins the First Circuit noted that the Port Authority was acting for the benefit of the public. See note 68 supra and accompanying text. The Third Circuit in Duke \& Co. v. Foerster, 521 F.2d 1277 (3d Cir. 1975) did not address the question as to whom the alleged boycott was designed to benefit. 
In Hecht v. Pro-Football, Inc. ${ }^{72}$ the District of Columbia Circuit was faced with a case where no such distinction could be made. There was no question that a public entity was involved. The court, however, refused to find that the anticompetitive activity of a government agency constituted state action absent a clear expression of intent by the legislature that the agency so act. ${ }^{73}$ The District of Columbia Armory Board had entered into a thirty-year lease with the Washington Redskins whereby the Armory Board agreed not to lease or rent the stadium to any other professional football team during the term of the contract. The Armory Board was empowered by statute "to determine all questions concerning the use of the stadium" and to rent or lease "all or any part or parts of the stadium" at such rent and "for such periods of time as the Board shall determine." 74 There was no showing that the restrictive covenant was necessary for the board to exercise its duty to lease the stadium, and the covenant was not "directly authorized" by Congress. ${ }^{75}$ The court therefore held that Parker was inapplicable, refusing to find the intent of the Armory Board determinative. ${ }^{76}$

72. 444 F.2d 931 (D.C. Cir. 1971), cert. denied, 404 U.S. 1047 (1972).

73. Similarly, in Duke \& Co. v. Foerster, 521 F.2d 1277 (3d Cir. 1975), the Third Circuit held that the grant of broad powers to municipal corporations to make contracts and do all things "necessary or convenient" for the management of municipal facilities was not sufficient to invoke Parker immunity since the alleged boycott could not be considered compelled by state law. $I d$. at 1281 .

Certain of the defendants undoubtedly had the statutory power to choose products to be sold through the concessions in the public facilities which they own and operate as a function of their authority to manage the facilities. However, nothing explicit or implicit in their statutory authority mandates or permits discrimination against certain suppliers.

Id. The court noted, however, that if the state's intent that an entity be allowed to employ anticompetitive measures could be inferred from the entity's duties and powers, Parker inmunity would apply. Id. at 1280 . See note 45 supra. Similarly, in City of Lafayette v. Louisiana Power \& Light Co. 532 F.2d 431 (5th Cir. 1976), cert. granted, 431 U.S. 963 (1977), the court held that municipal corporations are not automatically exempt from the antitrust laws:

Rather, a district court must ask whether the state legislature contemplated a certain type of anticompetitive restraint. In our opinion, though, it is not necessary to point to an express statutory mandate for each act which is alleged to violate the antitrust laws. It will suffice if the challenged activity was clearly within the legislative intent. Thus, a trial judge may ascertain, from the authority given a governmental entity to operate in a particular area, that the legislature contemplated the kind of action complained of.

532 F.2d at 434 (footnotes omitted).

74. 2 D.C. CODE $\S 1723$ (1973).

75. 444 F.2d at 934.

76. The court's attempt to distinguish Wiggins and Ladue is unconvincing. After emphasizing that in those cases states had created separate public service non-profit corporations as state agencies to perform functions the states could have performed for themselves, the court stated:

We suggest the obvious distinction of Wiggins Airways and Ladue Local Lines from the case at bar is that when Congress empowered the Armory Board to construct, maintain, and operate Kennedy Stadium, it was empowering the Armory Board to do what another governmental agency . . . could have done as straight forward federal governmental action, i.e., operate the stadium with full authority to rent to exhibitors of football games. On the rationale of Ladue and Wiggins such governmental agency action would not be subject to antitrust challenge, nor is the Board's management of 
Whether Parker requires a clear expression of state intent that anticompetitive measures be used to implement a state policy is unclear. ${ }^{77}$ Requiring such an intent raises several difficulties: the reason for a statute or regulation might have been considered too obvious to require expression or discussion, the inclusion of such purpose could be dependent on the skill or influence of its proponents, ${ }^{78}$ and the legislative history or other public record could be misinterpreted by the courts. ${ }^{79}$ Where there is a clear expression of state intent to restrict competition, it should be dispositive of the state action question, at least when the state has substituted some form of regulation. ${ }^{80}$ If the only expression of state intent is the creation of a regulatory agency, or the grant to a public agency of authority which could reasonably be construed to include anticompetitive activities, the decision is more difficult. The principles of federalism expressed in Parker, however, argue strongly for a finding of state action in such situations if there is evidence that the activity represents the considered judgment of the agency. ${ }^{81}$ The application of the Hecht approach to state agencies is not necessary to further the objectives of the Sherman Act and may unduly restrict a state from legislating in the public interest. When the entity is not considered to be a public

the stadium per se challenged. But what Congress did not do is create the Board as an instrumentality to own and operate the only professional football team to be allowed to play in the stadium; hence, neither the Board nor the Redskins in this case are performing a function that a purely governmental agency itself could have performed.

Id. at 939. How granting the Redskins an exclusive lease transformed the Board from the manager of the stadium to the manager of the Redskins is not clear, especially since there was no showing that at the time the lease was entered into there was any other professional football team desiring to lease the stadium.

77. The Court stated in Parker that the Sherman Act was not intended to restrain "a state or its officers or agents from activities directed by its legislature," 317 U.S. at 350-51 (emphasis added), or "state action or official action directed by a state." Id. at 351 (emphasis added). This language would seem to require an intent by the state itself that anticompetitive activity be undertaken. In applying its interpretation of the Sherman Act to the specific program challenged, however, the Court noted that California, acting through the Commission, had adopted and enforced the program and subsequently rephrased it as "the state in adopting and enforcing the prorate program." Id. at 352. Thus, at least where the statutory grant of authority contemplates anticompetitive measures an intent to allow the specific action taken by the state agency or official may be inferred. See note 73 supra.

78. Cantor, 428 U.S. at 610.

79. One commentator has expressed concern that if the courts apply the clear statement and active regulation requirements with insufficient force, the state may only be forced to "make a record" to legitimate regulation and that may not be sufficient to protect the policies of the federal antitrust laws. The Supreme Court, 1975 Term, 90 HARV. L. REV. 56, 237 n.54 (1976).

80. Even if the Court were to adopt a balancing test such as that proposed by Mr. Justice Blackmun in his concurring opinion in Cantor, 428 U.S. at 610 , state sanction of anticompetitive activity would be an important factor in favor of holding the antitrust laws inapplicable.

81. See text accompanying note 87 infra. Requiring such evidence would provide protection in situations like that in Woods, where there was little indication the state agency was aware of the potential consequences of its action. 
agency, as in Asheville Tobacco, requiring a clearer expression of intent seems justified.

2. State Involvement in Anticompetitive Activity. State involvement in anticompetitive activity in the form of approval, adoption, supervision or compulsion is most significant to the state action inquiry in the context of regulated industries. In such cases, the courts typically do not inquire into state intent, probably assuming that an intent to restrict competition is inherent in the creation of the regulatory agency.

There no longer seems to be any doubt that the antitrust laws apply to public utilities. ${ }^{82}$ It remains unclear, however, under what circumstances the Sherman Act actually proscribes any of their activities. For a utility's action to be protected under the Parker doctrine, the courts generally have required either that the final decision about a challenged activity be made by the state regulatory agency or that the particular activity be subject to its supervision. ${ }^{83}$ Most courts have required more than a mere power to control on the part of the regulatory agency. ${ }^{84}$ The Fourth Circuit, however, in a much criticized decision, ${ }^{85}$ upheld promotional activities by an electric company on the ground that because the State Corporation Commission had the power to stop such activities, its initial silence more likely indicated approval than abandonment of administrative duty. ${ }^{86}$ The Fifth Circuit has applied the Parker exclusion to rates and practices of monopolistic public utilities when they are "subjected to meaningful regulation and supervision by the state to the end that they are the result of the considered judgment of the state regulatory authority."

82. See generally Cantor, 428 U.S. at 596 n.35; Otter Tail Power Co. v. United States, 410 U.S. 366 (1973).

83. The Fifth Circuit recently stated: "We can scarcely envision a function more particularly 'sovereign' than the implementation of a rate structure on a public utility," and "regulation by a governmental body of the rates to be charged by a public utility are [sic] a classic example of the Parker v. Brown exemption." Jeffrey v. Southwestern Bell, 518 F.2d 1129, 1133-34 (5th Cir. 1975).

84. See, e.g., Marnell v. United Parcel Serv., Inc., 260 F. Supp. 391, 409-10 (N.D. Cal. 1966). The court held that mere power to control did not constitute state action where the agency had failed to exercise that power.

85. Washington Gas Light Co. v. Virginia Elec. \& Power Co., 438 F.2d 248 (4th Cir. 1971 ).

86. Id. at 252 . It is interesting that the court prefaced its holding with a quote from its decision in Allstate Ins. Co. v. Lanier, 361 F.2d 870, 872 (4th Cir.), cert. denied, 385 U.S. 930 (1966), in which it stated that to constitute state action for the purposes of Parker, action by private individuals must be under the active supervision of the state. $438 \mathrm{~F} .2 \mathrm{~d}$ at 251 . Although silence hardly seems equivalent to active supervision, the court noted the Commission's subsequent modification and then disapproval of the electric company's actions, which perhaps did indicate initial approval and thus a more active supervision than would appear at first glance. Id. at 252 .

87. Gas Light Co. of Columbus v. Georgia Power Co., 440 F.2d 1135, 1140 (5th Cir. 1971), cert. denied, 404 U.S. 1062 (1972). 
of the state, not only in its power to control the challenged rate schedule but also in its exercise of such control through holding adversary proceedings on each schedule and then ordering them into effect, sometimes with major modifications. ${ }^{88}$

The Supreme Court has indicated that where a specific activity is not directly authorized by statute but only permitted under a general statutory grant of authority, no state action will be deemed to exist unless the specific activity is subsequently adopted by the state or its agents. In Continental Ore Co. v. Union Carbide \& Carbon Corp ${ }^{89}$ a subsidiary of Union Carbide was delegated authority by a Canadian agency to purchase and allocate all vanadium products required by Canadian industries. The Court stated that although discriminatory purchasing by the subsidiary might be considered permissible under Canadian law, it was clearly not required and was therefore subject to the antitrust laws. ${ }^{90}$ The Court, however, did not base its decision on the absence of intent to restrict competition, but on the finding that no officials within the Canadian government had approved or would have approved of any efforts to monopolize the production and sale of vanadium or had directed discriminatory purchasing. ${ }^{91}$ It appears, therefore, that such approval or direction by an agent of the government might have insulated the activity from the antitrust laws.

In Goldfarb the Court examined both the intent of the state ${ }^{92}$ and its involvement in the challenged activity in rejecting a claim that the adoption of minimum fee schedules by state and county bar associations constituted state action. No state law expressly required minimum fee schedules. The Virginia Supreme Court, empowered by statute to regulate the practice of law, had suggested reference to "[t]he fee customarily charged in the locality for similar legal services"93 in order to avoid excessive fees. Although suggested fee schedules of state and local bar associations could be used to determine such customary fees, the court had indicated that "no lawyer should permit himself to be controlled thereby." 94 Thus, the state bar could at best claim that its adoption of the mandatory ${ }^{95}$ fee schedule was prompted by the ethical opinions of the state supreme court. The Supreme Court held that this did not constitute state action since it was not "compell-

88. 440 F.2d at $1139-40$.

89. 370 U.S. 690 (1962).

90. Id. at 706-07. This could be interpreted as requiring that a statute contemplate and specifically require the anticompetitive activity. See note 73 supra.

91. 370 U.S. at 706.

92. See notes 44-49 supra and accompanying text.

93. Virginia Code of Professional Responsibility, DR 2-106(b) (3), 211 Va. 295, 313 (1970).

94. Rules for Integration of the Virginia State Bar, 171 Va. xvii, xxiii (1938).

95. The fee schedule was mandatory only in the sense that repeated departures from the schedule could give rise to disciplinary action. 421 U.S. at 791 n.21. 
ed by direction of the State acting as a sovereign." 96 As in Continental Ore, the Court left open the question of whether approval would have provided sufficient state involvement to shield the action from the antitrust laws.97 However, the Court's statement that the activity must be required by the state in order to meet the threshold inquiry about state action ${ }^{98}$ suggests a stricter standard than that normally applied in the public utility cases where the exercise of control over anticompetitive activities has been held sufficient. ${ }^{99}$ Though the Court did not define what would constitute compulsion by the state, ${ }^{100}$ the term does not seem to include general supervision or even subsequent approval of specific activities. ${ }^{101}$

In reaching its decision, the Court appeared to be more influenced by the expressed intent that attorneys not be bound by the fee schedules than by the insufficient state involvement in the activity as revealed by its failure to require or even approve the fee schedule. If the lack of compulsion in Goldfarb is considered important primarily as an indication of state intent, then in cases where an anticompetitive intent can be inferred from the degree of state involvement, a lack of compulsion would not be determinative. ${ }^{102}$

96. Id. at 791 .

97. Id.; Robinson, supra note 66 , at 195 n.32.

98. 421 U.S. at 790.

99. See notes $82-88$ supra and accompanying text.

100. One commentator writing after Goldfarb has defined state compulsion as meaning that "compliance with the Sherman Act would cause a defendant to violate a prohibitory state statute, or would prevent a state agent from fully carrying out the duties delegated to him." Note, supra note 45 , at 725 . Under this definition, anticompetitive conduct by a regulatory board could be considered compelled without a specific statutory provision if it were deemed necessary to the board's duties. See Hecht v. Pro-Football, Inc., 444 F.2d 931 (D.C. Cir. 1971), cert. denied, 404 U.S. 1047 (1972), discussed at notes 72-76 supra and accompanying text.

The Supreme Court's recent decision on attorney advertising of fers at least one example of what constitutes state compulsion. In holding that the Arizona Supreme Court's rules prohibiting such advertising were not liable to antitrust attack, the Court distinguished Goldfarb:

In the instant case, by contrast, the challenged restraint is the affirmative command

of the Arizona Supreme Court under its Rules 27(a) and 29(a) and its Disciplinary

Rule 2-10(B). That Court is the ultimate body wielding the State's power over the practice of law. . . . and, thus, the restraint is "compelled by direction of the State acting as a sovereign.'

Bates v. State Bar of Arizona, 97 S.Ct. 2691, 2697 (1977) (quoting Goldfarb v. Virginia State Bar, 421 U.S. 773, 791 (1975)). The Court did not reach the question of whether anything less than an affirmative command by the entity with uitimate power would have sufficed.

101. The Cantor decision further complicates the state action question for regulated industries by holding that approval and compulsion may not be sufficient to insulate a utility's action from the antitrust laws. See notes 154-60 infra and accompanying text.

102. Even under this interpretation of Goldfarb, however, its standard would likely preciude a finding of state action where the state involvement is insufficient to imply an intent that a particular anticompetitive activity be used to implement a state policy. See, e.g., Washington Gas Light Co. v. Virginia Elec. \& Power Co., 438 F.2d 248 (4th Cir. 1971); Alabama Power Co. v. Alabama Elec. Coop., Inc., 394 F.2d 672 (5th Cir.), cert. denied, 393 U.S. 1000 (1968). There is some indication that the Fifth Circuit has moved to a stricter standard than that in Alabama Power. In that case the court held that a borrower who had obtained requirements contracts 
Goldfarb therefore appears to suggest that the inquiry into the degree of state involvement is a substitute for the inquiry into state intent, and involves similar considerations-whether or not the action is truly that of the state. ${ }^{103}$ Accordingly, if the state agency, acting within the scope of its authority, makes a determination based upon its considered judgment that an anticompetitive activity is desirable, state involvement should be considered sufficient to warrant exemption from the antitrust laws.

\section{B. The Second Inquiry: The Parker Exceptions}

Even if a court finds state action, it still must determine if a challenged activity is within one of the two exceptions described in Parker. If the state has effectively authorized a private violation of the Sherman Act or if it has joined in a private anticompetitive agreement, Parker is inapplicable. ${ }^{104}$ Though the two exceptions are more easily stated than the requirements for state action, they are at least as difficult to apply. In making a determination with respect to state action, a court can examine factual similarities to Parker and look to its experience in constitutional law for guidance. ${ }^{105}$

with electricity distributors as security required for a loan from the Rural Electric Administration was immune from suit under the antitrust laws since there was no provision for court review of the REA loans. Thus a broad statutory grant of authority was deemed sufficient to allow the adoption of anticompetitive measures. 394 F.2d at 674-77. Judge Godbold dissented on the grounds that an express delegation of authority to use anticompetitive measures was necessary to confer immunity on the administrator and the borrower. $I d$. at 680-81. The District of Columbia Circuit in Hecht interpreted the Fifth Circuit's decision in Woods as a "significant shift" toward Judge Godbold's approach. 444 F.2d at 934-35 n.6. In Gas Light Co. of Columbus v. Georgia Power Co., 440 F.2d 1135 (5th Cir. 1971), the Fifth Circuit found state action in the Georgia Public Service Commission's approval of rate schedules. The court noted the Commission's "intimate involvement" in the ratemaking process through giving lengthy consideration to the schedules, holding full adversary hearings, and at times making modifications. Id. at 1140. The schedules were thus products of the "considered judgment" of the Commission. Id. Though this may indeed represent the adoption of a stricter standard, it is not clear that the Fifth Circuit would not have found state action with a less favorable fact situation.

In City of Lafayette v. Louisiana Power \& Light Co., 532 F.2d 431, 435 (5th Cir. 1976), cert. granted, 431 U.S. 963 (1977), the court noted that "the argument that lower state entities are automatically exempt from the Sherman Act has been laid to rest by the Supreme Court in Goldfarb. The test now is whether the challenged action is the type of activity which the legislature intended the governmental body to perform." The court distinguished Alabama Power as involving the problem of reconciling various federal statutes. 532 F.2d at 435-36 n.10.

103. See, e.g., Woods Exploration \& Producing Co. v. Aluminum Co. of America, 438 F.2d 1286 (5th Cir. 1971), cert. denied, 404 U.S. 1047 (1972).

104. 317 U.S. at 351-52. If a given set of facts seems to fall within one of the Parker exceptions, it could be characterized as not constituting state action at all. This seems particularly true in the second exception where the state can be said to have waived its sovereign status. However, since "authorization" could take the form of a permissive state statute, see notes 51-55 supra and accompanying text, activity within the first exception would clearly seem to be state action by any definition.

105. Though the two inquiries are not thought to involve the same considerations, the Court in Cantor referred to Jackson v. Metropolitan Edison Co., 419 U.S. 345 (1974), as involving an 
There is little guidance, however, for the application of the exceptions, and unless they are interpreted on their most simplistic level-where the state suspends operation of the Sherman Act within its borders or acts in the role of a private individual - their meaning is unclear. While some courts have interpreted the exceptions in this way, others have taken a much broader view, perhaps out of a desire to restrict the scope of the Parker doctrine by expanding the exceptions. ${ }^{106}$ Such expansive interpretations have further blurred the poorly defined distinctions between the general rule of Parker and its exceptions, making it difficult to determine whether a court is rejecting a claim to immunity because there is no state action or because the state action involved falls within an exception.

1. State Authorization of Sherman Act Violations. After sweeping language allowing an exclusion of state action from the reach of the Sherman Act, Parker set out the first exception: "True, a state does not give immunity to those who violate the Sherman Act by authorizing them to violate it, or by declaring that their action is lawful." 107 As support for this proposition, the Court cited Northern Securities Co. v. United States, ${ }^{108}$ in which it had held that a railroad holding company, though permitted under New Jersey law, was nonetheless subject to the Sherman Act. The wording of the exception seems to contemplate two separate parties-the state and "those who violate the Sherman Act" - and to reflect the Court's belief that the former cannot immunize the latter from the sanctions of a federal law either by "authorizing" them to act in disregard of the Sherman Act or by declaring that their actions in violation of the Act are nonetheless lawful. Interpreted thus, the exception stands for the proposition that a state cannot suspend the operation of the Sherman Act within its borders-hardly surprising in light of the supremacy clause.

This narrow interpretation of the first exception has not been adopted, however. Rather, courts have considered minimal state involvement to

analogous situation in which state action was not found because the option to engage in the challenged activity was the public utility's, despite nominal approval by the regulatory authority. Id. at 357, cited in Cantor, 428 U.S. at 594 n.31. The dissent disagreed with the plurality's use of Jackson, noting that:

[T] ]his constitutional holding has no bearing on whether a utility's action in compliance with a tariff which it proposed is exempt from Sherman Act liability. The latter is a question of legislative intent, not constitutional law, and must be answered on the basis of a separate line of authority-namely, decisions such as Parker and [Eastern Railroad Presidents Conference v.] Noerr [Motor Freight, Inc., 365 U.S.

127 (1961)] which have construed the Sherman Act.

428 U.S. at $624-25$ n. 10.

106. One commentator has perceived a desire on the part of a significant number of lower courts to narrow the Parker antitrust exemption. Slater 91.

107. 317 U.S. at 351 .

108. 193 U.S. 197, 350 (1904). 
constitute implicit authorization of private anticompetitive activity. In Northern Securities, for example, the state's involvement could be construed as nominal at most, since the only claim to state authorization lay in the fact that the state corporation laws permitted the type of holding company in question. ${ }^{109}$ Similarly, the Third Circuit in Norman's on the Waterfront, Inc. $v$. Wheatley ${ }^{110}$ decided that such nominal state action was not protected by Parker, apparently considering it within the first exception. A Virgin Islands statute required the listing by wholesalers and retailers of minimum prices for their products and then prohibited sales below those prices. The court held that since the control board had "no power to approve, disapprove or modify the prices fixed by private persons," 111 there was insufficient governmental involvement to invoke Parker. ${ }^{112}$ Instead of "genuine governmental action controlling the anticompetitive practice,",113 the mandatory price stabilization scheme constituted "an attempt by government officials to authorize individuals to perform acts which violate the antitrust laws.",114

The difficulty in this approach to the first exception lies in distinguishing state authorization from state control of the anticompetitive activity. The Third Circuit seems to have employed a quantitative test, although the Norman's opinion is not entirely clear on this point. ${ }^{115}$ The fact that the Board had no power to approve, disapprove or modify the prices was apparently interpreted as indicating a lack of sufficient involvement by the government. Requiring genuine governmental action controlling the activity

109. See note 171 infra.

110. 444 F.2d 1011 (3d Cir. 1971).

111. Id. at 1018 .

112. The court also found that the statute was not valid under the McGuire Act, 15 U.S.C. $\S$ 45(a)(2)-(5) (1970), which, though allowing "states to authorize voluntary price maintenance agreements and to require retailers not parties to such agreements to adhere to the prices set therein . . . does not go so far as to permit a state or territory to enact a mandatory price stabilization scheme." 444 F.2d at 1016 (emphasis by court).

113. 444 F.2d at 1018.

114. Id.

115. The court's discussion of other cases offers little clarification. The court noted that the Supreme Court in Parker had "emphasized the extensive government involvement" in the California marketing program, id. at 1017 , and referred to several cases in which courts had looked to the degree of state involvement. E.g. , Gas Light Co. of Columbus v. Georgia Power Co., 440 F.2d 1135 (5th Cir. 1971), cert. denied, 404 U.S. 1062 (1972) (active regulation by the state, including full adversary hearing on rates); Allstate Ins. Co. v. Lanier, 361 F.2d 870 (4th Cir.), cert. denied, 385 U.S. 930 (1966) (insurance rates set by bureau created and actively supervised by the state). In several instances, however, the type of state involvement seems as significant as the degree-the ability of the bureau in Lanier to approve, disapprove and modify the rates, the similar ability of the Commission in Gas Light to modify rate schedules after adversary hearings, and the ability of the State Corporation Commission in Washington Gas Light Co. v. Virginia Elec. \& Power Co., 438 F.2d 248, 252 (4th Cir. 1971) to prohibit challenged promotional allowances despite its initial silence on the issue. 444 F.2d at 1017-18. 
could therefore be construed as requiring pervasive governmental participation. The government's inability to approve, disapprove or modify could be seen, however, as indicating a lack of the proper type of governmental action for Parker purposes. The court's use of the words "genuine," "controlling" and "authorize" suggest that it may have felt the government's action was insufficient in a qualitative as well as a quantitative sense. If a purely quantitative test is employed, the first exception would merely require that more than nominal state involvement be found, regardless of the nature of that involvement. Such an interpretation is especially troublesome in light of the fact that even "nominal state involvement" has already been deemed sufficient by the court to satisfy the threshold requirement of state action. ${ }^{116}$ In many cases pervasive state involvement would satisfy both tests. It is possible, however, that a state might delegate most of the activities necessary to implement an anticompetitive policy and still maintain effective control, thereby meeting only a qualitative standard. The approach in Norman's would not allow the application of Parker in the latter situation.

A similar interpretation of the first exception may have prompted the Supreme Court's reference to Parker in Schwegmann Bros. v. Calvert Distillers Corp. ${ }^{117}$ Schwegmann involved an attempt by distributors of gin and whiskey in interstate commerce to enjoin a retailer from selling the distributors' products at less than the minimum resale price established in contracts with other retailers in Louisiana. A Louisiana statute authorized such contracts and provided that once a seller learned of the existence of such a contract between a distributor and any retailer in the state, his sale of the product at less than the stipulated price would constitute unfair competition. ${ }^{118}$ The distributors contended that this marketing arrangement was authorized by the Miller-Tydings Amendment to the Sherman Act, which provides that "nothing herein contained shall render illegal, contracts or agreements prescribing minimum prices for the resale" of particular commodities when local law makes "contracts or agreements of that description . . . lawful as applied to intrastate transactions." 119 When the amendment was passed, non-signer clauses formed integral parts of each of the fortytwo state fair trade statutes then in effect; an earlier California fair trade

116. See notes 82-103 supra and accompanying text. One commentator has proposed a "pervasive regulatory scheme test" under which an exemption would be found only if the state had entrusted an agency with "the power both to administer a comprehensive regulatory scheme . . . and to adjudicate antitrust issues." Note, supra note 38 , at 410 . In other words, the state must provide sufficient control to perform the antitrust function. Id. 416.

117. 341 U.S. 384 (1951).

118. LA. GEN. STAT. $\$ \$ 9809.1-.6$ (Bobbs-Merrill 1939). The current version of the statute is found at LA. REV. STAT. ANN. \$§ 51.391-.395 (West 1965).

119. Miller-Tydings Act of 1937, 15 U.S.C. $\S 1$ (1970). 
statute without a non-signer clause had proved ineffective. ${ }^{120}$ Nevertheless the Court held that the amendment exempted only resale price agreements between a wholesale supplier and its retailers. Therefore, attempts to bind non-signers to those contracts fell within the scope of the Sherman Act. ${ }^{121}$ Though it did not directly address the issue, the Court apparently felt that the state statute also failed to exempt attempts to bind non-signers since they fell within the first Parker exception. "[W]hen a state compels retailers to follow a parallel price policy, it demands private conduct which the Sherman Act forbids." 122

The Court's narrow interpretation of the Miller-Tydings Amendment ${ }^{123}$ may have justified its conclusion that actions pursuant to the Louisiana statute were not thereby exempted from the prohibitions of the Sherman Act, but the implications of its reference to Parker are bothersome. The intention of Louisiana to allow such anticompetitive effects was evident from its fair trade laws, and the state provided a means for enforcing fair trade contracts through its courts. ${ }^{124}$

The Court, however, did not consider this state action of the type protected by Parker. If this was not sufficient state involvement to invoke Parker, the implication is that the state itself must implement the anticompetitive activity. Following the statement of the two exceptions, the Parker Court did stress the amount of state involvement, ${ }^{125}$ and implied that if

120. 341 U.S. at 398 (Frankfurter, J., dissenting).

121. 341 U.S. at 389 . The Court stated that prohibitions against "horizontal price fixing by those in competition with each other at the same functional level" were expressly continued, and interpreted horizontal price fixing to include enforcement of fair trade agreements against non-signers. Id. Congress, however, did not accept this interpretation and enacted the McGuire Act, 15 U.S.C. \& 45(a)(2)-(5) (1970), as an amendment to section 5 of the Federal Trade Commission Act, to allow states to include non-signer provisions in their fair trade laws. Norman's on the Waterfront, Inc. v. Wheatley, 444 F.2d 1011, 1015 (3d Cir. 1971).

122. 341 U.S. at 389. The statement in Schwegmann that "[t]he fact that a state authorizes the price fixing scheme does not, of course, give immunity to the scheme, absent approval by Congress," id. at 386, has been cited as support for the position that Parker does not apply to any anticompetitive activity required by the state unless there is a federal "enabling statute." The Court in Schwegmann, however, was addressing only the implementation of a federal authorization of a particular type of price fixing by private individuals through the vehicle of state fair trade laws. It determined that Louisiana's statute went further than Congress had intended in enacting the Miller-Tydings Amendment. Even if the Schwegmann Court's analysis is applicable beyond the context of the Miller-Tydings Amendment, it is highly doubtful, especially in light of its one casual reference to Parker, id. at 389, that the Court intended thereby to limit the Parker holding. It seems more likely that the Court felt the situation in Schwegmann would fall within the first of Parker's exceptions.

123. $444 \mathrm{~F} .2 \mathrm{~d}$ at 1015.

124. It has been suggested that the state compulsion in Schwegmann may have been simply too circuitous to give rise to Parker immunity. Simmons \& Fornaciari, State Regulation as an Antitrust Defense: An Analysis of the Parker v. Brown Doctrine, 43 U. CINN. L. Rev. 61, 66-67 (1974).

125. "It is the state which has created the machinery for establishing the prorate program. Although the organization of a prorate zone is proposed by producers, and a prorate program, 
private individuals used state-established machinery to effectuate an otherwise illegal anticompetitive scheme, such nominal state involvement would not be shielded from the antitrust laws. ${ }^{126}$

Louisiana's action in Schwegmann could be so construed. ${ }^{127}$ The language of the Court in Schwegmann is not so limited, however, since it refers to a state compelling or demanding anticompetitive private conduct. If this is considered a restatement of the first Parker exception, it is difficult to imagine instances of private action which would be protected by Parker. ${ }^{128}$

2. State Participation in Private Anticompetitive Conduct. The second Parker exception includes situations wherein the state or one of its subdivisions becomes "a participant in a private agreement or combination by others for restraint of trade." 129 Although no case law exists that specifically interprets the second exception, it apparently means that only state action in a sovereign capacity and not in a proprietary capacity is protected by Parker. ${ }^{130}$

Such an interpretation is supported by dicta in Continental Ore. ${ }^{131}$ The

approved by the Commission, must also be approved by referendum of producers, it is the state, acting through the Commission, which adopts the program and which enforces it with penal sanctions, in the execution of a governmental policy." 317 U.S. at 352.

126. The Court stated that the approval of the California prorate program by referendum of producers was "not the imposition by them of their will upon the minority by force of agreement or combination which the Sherman Act prohibits." Id.

127. Such a construction is strained, however, since allowing the enforcement of fair trade contracts against non-signers served to execute a governmental policy against what Louisiana considered unfair competition. 341 U.S. at 387 n.2. A distinction can be drawn between Parker and Cantor on the basis of absence of governmental policy since the Court found Michigan's policy toward the distribution of light bulbs to be neutral. Cantor, 428 U.S. at 585. See text accompanying notes $158-60$ infra.

128. The Cantor plurality reached the conclusion that Parker was not intended to protect private conduct and declined to extend its protection to such conduct unless failure to do so would be unjust. 428 U.S. at 489-93. See notes $163-78$ infra and accompanying text.

129. 317 U.S. at $351-52$.

130. Such an interpretation is suggested by the remainder of the paragraph in which the Court stressed California's involvement as a state in the California Prorate Program:

It is the state which has created the machinery for establishing the prorate program ... [I]t is the state, acting through the Commission, which adopts the program and which enforces it with penal sanctions, in the execution of a governmental policy .... The state itself exercises its legislative authority in making the regulation and in prescribing the conditions of its application.

$I d$. at 352 . Though private individuals were involved in the California program, the activity was still governmental in nature, imposed by the state as sovereign.

This interpretation aiso seems supported by the case cited following the statement of the exception. Union Pac. R.R. v. United States, 313 U.S. 450 (1941), involved a city council resolution giving produce dealers free rent and moving expenses to encourage them to move to a new produce market constructed and promoted by the city and railroad in a joint venture. The Court held the discriminatory rates to be in violation of the Elkins Act, 49 U.S.C. $\$ \$ 41-45$ (1970), rejecting the claim that the participation of a political subdivision of the state gave the railroad immunity.

131. See notes 89-91 supra and accompanying text. "The fundamental distinction between Parker and Continental Ore was that governmental action in Parker consisted of a regulatory 
Court noted in that case that the corporate defendants were "not insulated by the fact that their conspiracy involved some acts by the agent of a foreign government," when those acts were not approved or compelled by Canadian law but were merely designed to eliminate a competitor of the agent's parent corporation. ${ }^{132}$ This distinction was also made in Goldfarb. The Court found that the state bar, in adopting and enforcing the minimum fee schedule, was acting for the benefit of its own members outside of its authority to administer regulations of the state supreme court. It was therefore merely a participant in private anticompetitive action and not excepted from the operation of the Sherman Act. ${ }^{133}$

If this exception is limited to proprietary acts of a state, it is not problematic, since courts must frequently make this distinction. Continental Ore and Goldfarb, however, do not use the term "proprietary," and in Union Pacific at least part of the city's involvement was in a governmental capacity. ${ }^{134}$ If the words of Parker in describing the exception are not given this interpretation, however, courts would have to weigh the relative degree of involvement of the state and the private parties to determine if the latter is sufficiently dominant to prevent the activity in question from constituting

program while the governmental action in Continental Ore involved direct participationbuying vanadium as would a private concern." Note, Antitrust-Immunity-Government Participation Does Not Exempt a Lease from the Antitrust Laws Absent an Unequivocal Manifestation of Contrary Congressional Intent, 50 TEX. L. REV. 1017, 1020 (1972).

132. 370 U.S. at 706 .

133. 421 U.S. at 791-92. See Duke \& Co. v. Foerster, 521 F.2d 1277 (3d Cir. 1975), in which the court held that a municipal corporation was not immune from suit for allegedly conspiring to boycott one supplier's products in managing public facilities. The court stated:

After Goldfarb .... it is clear that when there is an allegation of governmental participation in such a combination to the benefit or detriment of private parties, and when the activities of the public body are not compelled by the state acting as a sovereign, a claim has been stated under the antitrust laws.

Id. at 1282. See note 73 supra. See also City of Lafayette v. Louisiana Power \& Light Co., 532 F.2d 431, 434 (5th Cir. 1976), cert. granted, 431 U.S. 963 (1977).

134. See Union Pac. R.R. v. United States, 313 U.S. 450 (1941). Three circuits have rejected the distinction between governmental and proprietary actions for purposes of Parker. In Ladue, the Eighth Circuit stated that even if sovereign immunity had been waived in the challenged bi-state compact, or by the states' engaging in a proprietary action, the states were still not liable under the antitrust laws. 433 F.2d at 135-36.

In City of Lafayette v. Louisiana Power \& Light Co., 532 F.2d 431, 434 n.8 (5th Cir. 1976), cert. granted, 431 U.S. 963 (1977), the Fifth Circuit noted:

[W] cannot accept defendant's invitation to import the discredited proprietarygovernmental distinction into this area of the law. This contention is unsupported by authority and is irrelevant under Parker and Goldfarb, which look only to the scope of the legislative action and not the "proprietary" or "governmental" nature of the subordinate governmental body's conduct.

See Slater 89-90. In a somewhat analogous situation the First Circuit has held that the NoerrPennington immunity from the antitrust laws for attempts to petition the government, Eastern Railroad Presidents Conference v. Noerr Motor Freight, Inc., 365 U.S. 127 (1961), expanded in UMW v. Pennington, 381 U.S. 657 (1965), was not applicable to attempts to influence the government in a proprietary capacity. George R. Whitten, Jr., Inc. v. Paddock Pool Builders, Inc., 424 F.2d 25 (1st Cir.), cert. denied, 400 U.S. 850 (1970). 
state action. The application of the second exception would then be similar to that of the first. Indeed, from the language employed by some courts, especially in cases involving regulatory boards, it is difficult to determine if they have found no state action or state action excepted from the Parker holding. ${ }^{135}$ The difficulty in defining the limits of the exceptions has complicated the task of the courts since the reach of the Sherman Act under Parker will not only include private anticompetitive activities but some state action, despite the broad language of the Parker Court.

\section{Dissatisfaction with the Parker Doctrine.}

In most instances, once a court has determined that the challenged activity is state action within the meaning of Parker, and not excepted from Parker's holding, its inquiry has ended. Some courts and commentators, however, have suggested that the inquiry should not be confined to a jurisdictional analysis. ${ }^{136}$ Instead, they have proposed various methods of preventing the action of a state from contravening the federal antitrust laws, ranging from abolishing the state action exemption ${ }^{137}$ to using a primary jurisdiction approach similar to that employed in federal agency adjudication. ${ }^{138}$ On the other hand, there is concern that without the Parker doctrine courts would use the federal antitrust laws to strike down state regulations considered unwise-a form of "substantive antitrust" review. ${ }^{139}$ Principles

135. For example, in Woods, the Fifth Circuit stated "[I]t is not every governmental act that points a path to an antitrust shelter," indicating that certain state actions would be excepted from Parker. 438 F.2d at 1294 . The court went on to phrase its inquiry in terms of whether the anticompetitive consequence was truly the action of the state, indicating a switch in inquiry to whether state action was present. Id. The court's finding that the actions of the large producers had not merged with the action of the state implies that it felt the challenged action was not state action, but this is rendered uncertain by the clear involvement of the Railroad Commission.

136. See, e.g., Hecht v. Pro-Football, Inc., 444 F.2d 931, 934 (D.C. Cir. 1971), cert. denied, 404 U.S. 1047 (1972) ("After a study of the rationale back of the decided cases in this area of antitrust law, we consider . . . the rule derived by appellees [that federal antitrust laws are inapplicable to direct governmental action as distinct from private conduct] is a much too talismanic approach where scrupulous distinctions are called for."); Woods Exploration \& Producing Co. v. Aluminum Co. of America, 438 F.2d 1286, 1294 (Sth Cir. 1971), cert. denied, 404 U.S. 1047 (1972) ("We reject 'the facile conclusion that action by any public official automatically confers exemption.' "); George R. Whitten, Jr., Inc. v. Paddock Pool Builders, Inc., 424 F.2d 25, 29 (1st Cir.), cert. denied, 400 U.S. 850 (1970) ("We are particularly reluctant to rely on verbal formulae to solve problems of antitrust liability.").

137. See Slater. Slater would replace the jurisdictional approach of Parker with a balancing test which would sustain state regulation "if the state could demonstrate that it had a valid reason behind its regulation and that the interest furthered by the regulation was of greater significance than preserving competition." Id. 104. A balancing test has also been proposed by Mr. Justice Blackmun in Cantor, 428 U.S. at 610-11, see text accompanying note 206 infra, and by the court in Hecht, see notes 72-76 supra and accompanying text, notes 142-48 infra and accompanying text.

138. Verkuil, supra note 39 , at 346-50.

139. Verkuil, supra note 39. 
of federalism emphasized in Parker suggest the necessity for some deference to the states' interest in regulating industry within their borders at least when such regulation is consistent with the underlying purposes of the federal antitrust laws. ${ }^{140}$ As has been noted, a judicial overruling of Parker would probably result in state withdrawal from various areas of commerce now under state regulation before Congress could act to provide substitute federal regulation. ${ }^{141}$

An interesting case in this regard is Hecht. ${ }^{142}$ The court rejected the argument that the leasing of a municipal stadium constituted government ${ }^{143}$ action within the meaning of Parker and proposed a six-part balancing test for determining whether government action should be immune from the federal antitrust laws. Factors to be considered in determining whether the state action was permissible as not contravening the federal antitrust laws would include:

[T] he specific language of the congressional statute involved, any legislative history which would throw light on the congressional intent, the relative importance of the governmental action which is asserted to override antitrust policy, whether the governmental agency is required to take into consideration the possible anticompetitive effect of its actions, whether the agency is required to adhere to a clearly defined and restricted statutory directive, and to what extent the agency's actions are subject to judicial review. ${ }^{144}$

Though Hecht involved the construction of two potentially conflicting federal statutes and thus did not present problems of federalism, the District of Columbia Circuit indicated that the test would also be applicable if a state statute were involved. ${ }^{145}$

Such a balancing test, recommended by Judge Godbold of the Fifth Circuit for federally regulated industries, ${ }^{146}$ would prevent the federal antitrust laws from being subordinated unless the state's interest was important, and might encourage consideration by the state of the anticompetitive

140. See note 39 supra. The essence of Parker has been described as the rule that when inconsistency between the antitrust laws and state regulation stems from different regulatory objectives rather than conflicting treatment of the same subject matter, the state regulation is not so repugnant to the federal statute as to be invalid. Handler, The Current Attack on the Parker v. Brown State Action Doctrine, 76 ColUM. L. Rev. 1, 15 (1976). And "the preservation of our federalism overrides whatever benefits might flow from extending the reach of antitrust by limiting the ambit of the state action defense." Id. 20.

141. Note, supra note 45 , at 721 .

142. See notes $72-76$ supra and accompanying text.

143. Since Hecht arose in the District of Columbia the case was concerned with federal governmental activity equivalent to state action.

144. 444 F.2d at 935 .

145. Id.

146. Alabama Power Co. v. Alabama Elec. Coop., Inc., 394 F.2d 672, 689-92 (5th Cir.), (Godbold, J., dissenting), cert. denied, 393 U.S. 488 (1968). 
implications of its regulations. As applied to two federal statutes, the balancing test would simply require a determination as to whether the latter is intended to modify the former. When a federal and a state statute are involved, however, the court must examine the federal statute to determine if it was intended to (and constitutionally did) preempt state regulation in that area. The Parker Court assumed that Congress could have reached programs such as the California Prorate Program under the commerce clause had it so intended, ${ }^{147}$ but found no indication of such intent. Though the Court's interpretation of the legislative history of the Sherman Act has been criticized, until Congress indicates disagreement with the Parker holding or the Court rejects Parker's jurisdictional premise, the approach suggested in Hecht should not be extended to state regulations. ${ }^{148}$

\section{The SuPreme COURT'S Re-eXAMination of PARKER: CANTOR V. DETROIT EDISON CO.}

After thirty years of virtual silence on the Parker state action exemption, ${ }^{149}$ the Court's discussion of state action in Goldfarb was primarily the enunciation of another "verbal formula"150 for recognizing state action. The decision provided an illustration of when a state agency was merely participating in a private agreement in restraint of trade. It also indicated that the Court was not ready to abandon the Parker doctrine. The basic question as to what constitutes state action within the meaning of Parker, however, was left unclarified. ${ }^{151}$

In Cantor, the Court was confronted with a challenge to a portion of a public utility's rate structure. ${ }^{152}$ The Court held that neither Michigan's

147. 317 U.S. at 350.

148. One commentator has suggested that although the reasons for granting a state action exemption differ from those for granting a federal action exemption, the Hecht test can be used for the former "because its central inquiry is into the intent of the legislature . . . to supplant the federal antitrust laws with some other form of regulation." Note, Parker v. Brown-Gone to Hecht: A New Test for State Action Exemptions, 24 HASTings L.J. 287, 288 (1973). While the intent of the legislature may indicate whether an anticompetitive activity constitutes state action, the balancing of state and federal interests envisioned by Hecht is inconsistent with the jurisdictional approach of Parker. See Simmons \& Fornaciari, supra note 124, at 73.

149. See note 34 supra. The few cases during this period which referred to the state action exemption did little to explain Parker's rationale or to offer guidelines for its application.

150. See note 136 supra.

151. Though the Court mentioned the absence of several factors which led to the conclusion that the minimum fee schedule was not required by the state, the very factors enumerated produce ambiguity in the Court's use of the words "required" and "compelled." It is unclear, for example, if approval by the Virginia Supreme Court of the ethical opinions of the State Bar setting out the minimum fee schedule would have been considered compulsion. See note 97 supra and accompanying text. The Court also left unanswered what was meant to follow its threshold inquiry as to whether the anticompetitive activity is "required by the State acting as sovereign." 421 U.S. at 790 . See note 178 infra.

152. The courts have frequently applied Parker in this situation. See note 83 supra. 
approval of the tariff nor the fact that the challenged program could not be terminated until a new tariff was approved was sufficient to exempt the program from the antitrust laws. ${ }^{153}$ Five Justices agreed with this conclusion, and Mr. Justice Blackmun concurred on the ground that neither state sanction of a scheme nor a state requirement of anticompetitive conduct itself exempted such conduct from the Sherman Act. Perhaps the most significant aspect of the decision is its affirmation of the state action exemption. Far from clarifying its scope, however, the differing approaches of the four opinions may well increase the difficulty of determining when the exemption will be applied.

In Cantor, the Detroit Edison Company, sole distributor of electricity in southeasteru Michigan, was alleged to be restraining competition in the distribution of light bulbs through its light bulb exchange program. ${ }^{154}$ Detroit Edison was pervasively regulated by the Michigan Public Service Commission which is empowered by statute to "regulate all rates, fares, fees, charges, services, rules, conditions of service, and all other matters pertaining to the formation, operation, or direction of . . . public utilities." 155 The Public Service Commission first specifically approved a tariff filed by Detroit Edison incorporating the light bulb exchange program in 1916 and implicitly reaffirmed its approval with each new tariff filed. ${ }^{156}$ Thus, though the light bulb exchange program was not carried on by Detroit Edison pursuant to any statutory directive, it had been formally approved by the regulatory agency according to its statutory authority. Moreover, until a new tariff was filed and approved, Detroit Edison was required to adhere to the tariff then in effect.

Despite nominal approval of the program through the Commission and nominal compulsion to maintain the program, the Court felt that the light bulb exchange program did not "implement any statewide policy relating to light bulbs," 157 since the distribution of light bulbs was unregulated, no other utility had such a program, and neither the Michigan legislature nor the Commission had investigated the need for or desirability of such a program or its anticompetitive effects. ${ }^{158}$ The Court ${ }^{159}$ concluded that the

153. 428 U.S. at 598.

154. The program was initiated in 1886 by Detroit Edison's predecessor to increase the consumption of electricity. Under the program a new customer receives as many bulbs as needed, then turns in burned out bulbs to receive replacements in proportion to his use of electricity for lighting. Though there is no direct charge for the bulbs, their cost is absorbed by the rates for electricity, allegedly saving consumers about $\$ 3$ million a year. Id. at 583 .

155. Mich. CoMP. LAWS ANN. \& 460.6 (West 1967).

156. 428 U.S. at 583. In 1964, Detroit Edison's decision to discontinue the program for large commercial customers was approved as part of a rate reduction for such customers. Id.

157. Id. at 585 .

158. Id. at $584-85$.

159. The Chief Justice concurred in this portion of the plurality opinion. 
state's policy was neutral as to whether a utility should have such a program. ${ }^{160}$

Given the state's neutral policy and its minimal involvement in the light bulb exchange program, ${ }^{161}$ the Court's conclusion that Detroit Edison's activity was not immune from the antitrust laws seems warranted. ${ }^{162}$ The plurality based its conclusion, however, on a misinterpretation of Parker, holding that because "the legality of any act of the State of Michigan or any of its officials or agents" was not questioned, Cantor was "not controlled by the Parker decision." 163 The Chief Justice, ${ }^{164}$ Mr. Justice Blackmun, ${ }^{165}$ and the dissent ${ }^{166}$ expressly rejected the novel interpretation that Parker only applied to acts of public officials. As they perceived it, the rationale of Parker and all previous case law "focused on the challenged activity, not upon the identity of the parties to the suit." 167 The Chief Justice, however,

160. 428 U.S. at 585.

161. The Court in Bates v. State Bar of Arizona, 97 S.Ct. 2691 (1977), described the Commission's action as only "acquiescence," reflecting "its conclusion that the utility was authorized to employ the practice if it so desired." Id. at 2698.

162. In its recent decision on the advertising of legal services, Bates v. State Bar of Arizona, 97 S.Ct. 2691 (1977), the Supreme Court held that the state supreme court's disciplinary rule prohibiting such advertising was not subject to attack under the Sherman Act. Mr. Justice Blackmun noted for the Court that the context in which Cantor arose was critical and distinguished it on three grounds. First, whereas in Cantor the suit was against a private party, in Bates the state supreme court was the real party in interest, the adopter of the rule and its ultimate enforcer. The state bar acted "as the agent of the court under its continuous supervision," in a role "completely defined by the court." Id. at 2697. Second, the regulation of the bar's activity was at the core of the state's power to protect the public, a traditional form of regulation "entirely unlike" the Cantor situation where the state had no independent regulatory purpose and the anticompetitive action was not justified by flaws in the market, responsive to health or safety concerns or essential to the regulation of the utility engaged in the activit\%. Finally, in Bates the rule reflected a clear articulation of state policy and was subject to reexamination in enforcement proceedings, while in Cantor the state regulatory commission merely acquiesced in the utility's action. Id. The Bates Court's emphasis on the state's clear and affirmative expression of policy and active supervision reflects the most frequent approach in other decisions under the Parker doctrine. See notes 39-103 supra and accompanying text. The Court did not reach the question whether Parker immunity extends to private parties who are not agents of the state or to regulation of an entity which is not essential to a primary governmental function.

163. 428 U.S. at $591-92$.

164. Id. at 604 (Burger, C.J., concurring).

165. Id. at 613 n.5 (Blackmun, J., concurring).

166. The dissent asserted that the plurality's "view of Parker, which would trivialize that case to the point of overruling it, flies in the face of the decisions of this Court that have interpreted or applied Parker's 'state action' doctrine, and is unsupported by the sources on ' which the plurality relies." Id. at 616-17 (Stewart, J., joined by Powell \& Rehnquist, J.J., dissenting) (footnote omitted).

167. Id. at 604 (Burger, C.J., concurring) (emphasis in original). "Significantly, the Court [in Parker] did not find the question of whether the state or the private sector initiated the plan or made proposals relevant to a determination of the presence of 'state action,' so long as those proposals were subject to the scrutiny of state officials." Note, supra note 38 , at 400 . See also Handler, supra note 140 , at 8. 
joined the plurality in the portion of its opinion which discussed, and rejected in this case, two reasons why private conduct required by state law might be held exempt from the Sherman Act. ${ }^{168}$

The first of these reasons was that it would be unjust to hold a private individual liable under the federal antitrust laws if he had done nothing more than obey the state's command. ${ }^{169}$ Although the Court assumed that such an argument might be acceptable, it offered no illustrations of when state participation would be so dominant that federal antitrust law enforcement would be unfair, and noted that such a situation would, in fact, rarely arise since regulatory cases typically "involve a blend of private and public decision-making." 170 The Court pointed out that in several prior decisions, ${ }^{171}$ " notwithstanding the state participation in the decision, the private

168. He apparently considered the plurality's discussion relevant to determining whether this particular private conduct was of the type protected by Parker. The plurality, on the other hand, clearly felt that exempting private conduct required by state law from antitrust liability would be an extension of the Parker doctrine.

169. 428 U.S. at 592.

170. Id. The dissent pointed out that "[a]s the Court seems to acknowledge, such regulation is heavily dependent on the active participation of the regulated parties, who typically propose tariffs which are either adopted, rejected, or modified by utility'commissions." Id. at 627.

171. The reference to these cases as deciding that state "authorization, approval, encouragement, or participation in restrictive private conduct confers no antitrust immunity," $i d$. at 592-93 (citations omitted), is indicative of the problems in this catchword approach to the scope of the state action exemption. Northern Sec. Co. v. United States, 193 U.S. 197 (1904), is cited for the statement: "It cannot be said that any State may give a corporation, created under its laws, authority to restrain interstate or international commerce against the will of the nation as lawfully expressed by Congress." Id. at 346, quoted in Cantor, 428 U.S. at 592 n.26. The contention actually rejected in Northern Securities was that a state's liberal incorporation laws immunized a corporation taking advantage of them to destroy competition even though the state had no reason to suspect the purpose behind the formation of the holding company. Indeed, in its application for a charter, the corporation had misrepresented its reasons for desiring a charter. The Northern Securities Court was probably attempting to dispel any ideas that the Sherman Act could not reach the activity of a corporation merely because it held a state charter. 193 U.S. at 344-47. The quoted statement did not remain part of an eloquent defense of federal power under the Sherman Act, however, but was used as the basis for the first exception in Parker. See text accompanying notes 107-09 supra. Any state conduct which could be characterized as "authorization" of anticompetitive conduct was thus potentially excepted from the state action exemption. A similar process may be initiated by this reference in Cantor. The Court cites Parker's statement that a state does not immunize those who violate the Sherman Act "by declaring that their action is lawful," 317 U.S. at 351 , as indicating that state "approval . . confers no antitrust immunity." 428 U.S. at 592-93. In Goldfarb, however, the Court left open the question as to whether the Virginia Supreme Court's approval of the state bar association's minimum fee schedule would have required a finding of state action. See notes $97-$ 103 supra and accompanying text. And, lack of approval by Canadian officials was one of the bases for finding no exemption in Continental Ore. See notes 89-91 supra and accompanying text. It seems unlikely that any word or phrase used in one case to characterize state action can be used in a subsequent case to define the scope of the state action exemption without an understanding and application of the policies behind the exemption. Otherwise the words must be continuously redefined to allow for new situations. Handler, supra note 140, at 13 has notcd that there is no logical reason or policy ground to differentiate between required, prohibited or permitted activity. Rather, the focus should be on whether the action challenged as a violation of the antitrust laws has been sanctioned by state law, whatever the form of sanction. 
party exercised sufficient freedom of choice to enable the Court to conclude that he should be held responsible for the consequences of his decision."172 Since the decision of whether to have the light bulb exchange program was "primarily" Detroit Edison's, its participation was "sufficiently significant" that it would not be unjust to require conformance with the antitrust laws. Accordingly, to resolve the state action question, a court must not only look to the degree of state involvement, as in prior cases, but must also determine whether "it would be unfair to hold a private party responsible for his conduct." 173 A court, therefore, must examine a factual situation from two perspectives-the nature and degree of both state involvement and private participation. Furthermore, it is unclear whether a quantitative or qualitative standard should be applied.

A quantitative approach would exclude from the state action exemption cases like Cantor, in which the state's involvement is so minimal as to imply that the state has not really considered the desirability of the anticompetitive activity. ${ }^{174}$ If used alone, however, it might produce anomalous results. While a large amount of state involvement may be a valid indication of the state's intent to restrict competition in a particular manner, the converse does not necessarily follow as long as there is some indication that the state considered the restriction. The state's degree of participation in the decision to institute an anticompetitive activity, especially if in the form of investigating its desirability, ${ }^{175}$ may be primarily a function of its novelty or controversial nature.

The Court's language is sufficiently ambiguous to allow for a qualitative approach. ${ }^{176} \mathrm{Without}$ any further guidance from the Court, however, it

Nevertheless, the Court in Cantor offered little guidance as to what the lower courts should attempt to achieve in applying the new tests for state action, if the two rationales can be so characterized.

172. 428 U.S. at 593.

173. Id. at 595. A determination that it would be unfair to hold a party liable for conduct mandated by the state might serve to prevent treble damages but not injunctive relief. Id. at 614 n.6 (Blackmun, J., concurring). See also Surety Title Ins. Agency, Inc. v. Virginia State Bar, 431 F. Supp. 298, 309 (E.D. Va. 1977); Slater 78 n.34.

174. Such nominal state involvement is apparently what the Fourth Circuit was referring to in Asheville Tobacco, 263 F.2d at 509, when it stated that Parker protected only state action, "not individual action masquerading as state action." See notes 62-66 supra and accompanying text. See also notes $115-28$ supra and accompanying text discussing the use of a quantitative test under the first exception. Under the First Circuit's interpretation of Asheville Tobacco, state policy was neutral toward the anticompetitive activity despite some regulation of the industry involved. George R. Whitten, Jr., Inc. v. Paddock Pool Builders, Inc., 424 F.2d 25 (1st Cir.), cert. denied, 400 U.S. 850 (1970).

175. The absence of any investigation of the desirability of a light bulb exchange program by the legislature or the Public Service Commission was an indication that the state's policy was neutral toward the program. 428 U.S. at 584.

176. Whether a private individual exercised "sufficient freedom of choice" or an "option to have, or not to have, such a program" or "sufficiently significant[ly]" participated in the 
is difficult to imagine what type of state participation would be sufficient, since the Court indicated that state authorization, approval, encouragement, participation, ${ }^{177}$ or, in Cantor, requirement, do not necessarily confer antitrust immunity. ${ }^{178}$

The second rationale discussed by the Court is that Congress might not have intended to superimpose the federal antitrust laws in an area of the economy pervasively regulated by a state. The plurality advanced three reasons to reject this contention: inconsistent standards would not necessarily be imposed; $;^{179}$ even assuming inconsistency, the federal interest should not inevitably be subordinated to that of the state; and distribution of electric light bulbs is not a regulated area of the economy. ${ }^{180}$ As the dissent re-

decision, id. at 593-94, could be determined by looking at the nature of the state's participation. This would also reveal whether the state's participation was dominant.

177. Id. at 592-93.

178. In a post-Cantor decision, one district court held that the issuance of advisory opinions by the state bar as to what constituted the unauthorized practice of law, though clearly sanctioned by the state, was nonetheless invalid under the antitrust laws since "the harms of the system greatly outweigh[ed] its purported benefits." Surety Title Ins. Agency, Inc. v. Virginia State Bar, 431 F. Supp. 298, 307 (E.D. Va. 1977). The court recognized the state's compelling interest in licensing practitioners and regulating the practice of law and that restricting practice to those duly licensed was a legitimate and necessary exercise of that power. Id. The court found, however, the unauthorized practice of law opinion process to be insufficiently related to those interests since the persons to be deterred were excluded from the advisory opinion practice and were already subject to criminal sanctions. Thus, the advisory opinion process was considered merely a means for allowing attorneys to define the extent of their own monopoly. Id. at 307-08. The court's holding rested to a large extent on its belief that the practice benefited the attorneys and not the public. Id. at 308-09. See note 39 supra. The problem with the court's analysis lies in its assumption that it is the role of the courts adjudicating an attack on the state-compelled process and not the state in formulating that process to determine the public interest and the best means of serving it. The court disclaimed any implication of ethical impropriety on the part of any members of the bar but felt that the "anticompetitive dangers inherent in the [unauthorized practice of law] opinion process" justified allowing antitrust attack, $431 \mathrm{~F}$. Supp. at $308 \mathrm{n} .17$, since the challenged activity was not necessary to accomplish the regulatory purpose. Id. at 307-08. The court "cautiously discern[ed]" this standard from the language in Cantor which it interpreted as establishing, albeit not entirely clearly, the further inquiry necessary after meeting Goldfarb's threshold requirement of compulsion.

Whether such a standard is proper is questionable after the recent Supreme Court decision on attorney advertising which held the Parker exemption applicable without determining that the prohibition on advertising was necessary to the state's regulation of the practice of law. Bates v. State Bar of Arizona, 97 S.Ct. 2691, 2698 (1977); see note 162 supra. The Bates decision further suggests that if the state is the real party in interest and the private party acted merely as its agent, he will be protected under Parker, 97 S.Ct. at 2697.

179. It has been suggested that the establishment of the exemption in Parker was in recognition of congressional desire to allow the states to experiment with alternative types of regulation. Therefore, the exemption would be unnecessary to effectuate congressional intent unless the application of the antitrust laws "would conflict with some positive regulatory action of the state," that is, where there existed a "plain repugnancy" between the federal laws and state regulation. Note, supra note 56 , at 1520 .

180. 428 U.S. at 595 . 
marked, it is somewhat difficult to perceive how these reasons relate to a determination of congressional intent. ${ }^{181}$ In discussing the first reason, the Court noted that the purpose of some economic regulation by a government is "to avoid the consequences of unrestricted competition," 182 citing as an example the agricultural marketing program in Parker. In contrast, public utility regulation is designed to protect the consumer from exploitation, since it typically assumes that the utility is a natural monopoly. ${ }^{183}$ The implication is that if state regulation is itself intended to restrict competition in a given area of the economy, Congress would not intend that the antitrust laws apply. On the other hand, where state regulation is designed to protect the consumer from exploitation by a natural monopoly, the goals of the antitrust laws and state regulation are consistent and Congress does intend the antitrust laws to apply. ${ }^{184}$ Therefore, an industry exercising its natural monopoly powers would be subject to both state regulation and federal antitrust regulation. It was not necessary, however, to make this distinction between the two types of regulation. The Court immediately qualified the distinction by noting that there was no logical inconsistency in requiring a utility to comply with state regulation when exercising its monopoly powers and with federal antitrust standards when engaging in activity in competitive areas of the economy. ${ }^{185}$ Thus, the Court seemed to admit that there might be inconsistency (and therefore presumably no congressional intent to superimpose the antitrust laws) between the antitrust laws and state regulation of the utility's natural monopoly powers. However, it felt that this case presented no problem since it was the utility's "activities in competitive

181. Id. at 627 .

182. Id. at 595 .

183. Id. at 595-96.

184. This apparent distinction between the two types of regulation is troublesome in several respects. First, it assumes that congressional intent as to the scope of the Sherman Act varies according to the nature of the entity regulated. There is no statutory statement to that effect. Second, it would apparently find congressional intent to impose the antitrust laws on an industry when competition was restricted by the nature of the industry, rather than by a decision of the state that such restriction would be desirable. See Cantor, 428 U.S. at 628-n.13. As long as the challenged activity is pursuant to state regulation it seems irrelevant whether the statute directs the entity to engage in anticompetitive activity in order to restrict competition, or presumes lack of competition and directs the entity to engage in activity which will perpetuate that presumption. Finally, assuming the latter point, it seems more likely Congress would have intended to impose the antitrust laws in areas of the economy which at the time the act was passed were unregulated, rather than on areas such as natural monopolies which were already being regulated when the Sherman Act was enacted. The dissent interpreted the legislative history of the Sherman Act as revealing "no intent to 'interfere with' state laws regulating domestic commerce." Id. at 635.

In Bates v. State Bar of Arizona, 97 S.Ct. 2691 (1977), however, the Court appears to have at least partially based its holding that a prohibition on attorney advertising was immune from antitrust attack on the ground that the practice of law is a profession traditionally regulated by the state. $I d$. at $2697-98$.

185. 428 U.S. at 596. 
markets" which were in question. ${ }^{186}$ It is difficult to follow the Court's reasoning on the question of inconsistent standards, but it seems to be based both on a determination that the distribution of light bulbs in Michigan was essentially unregulated ${ }^{187}$ and that it did not fall within the utility's natural monopoly powers.

The second reason discussed by the Court for refusing to find that Congress did not intend to superimpose antitrust laws on state regulated areas of the economy was that the mere possibility of conflict between state regulatory policy and federal antitrust policy is an insufficient basis for implying an exemption from the federal antitrust laws. ${ }^{188}$ The Court drew on those cases in which there was a conflict between the federal antitrust laws and the regulations of a federal agency in which the Court has held that "an implied repeal of the antitrust laws may be found only if there exists a 'plain repugnancy between the antitrust and regulatory provisions.' "189 Assuming that the existence of state regulation should in some situations produce such an exemption, the standards for determining the existence and scope of the exemption would therefore have to be as strict as those for federal agencies-finding an implied exemption only to the minimum extent necessary to make the regulation work. As the dissent points out, the plurality's analysis rests on a mistaken premise ${ }^{190}$ the doctrine of implied repeal is only applicable when two arguably inconsistent federal statutes are involved. The question is not whether the state has attempted to repeal the antitrust laws and thereby to exempt its citizens from the operation of a federal statute, as that would clearly violate the supremacy clause. The issue is whether Congress intended to preempt the area. ${ }^{191}$ Under the Parker doctrine, the act of the state has the effect of exempting activities from the Sherman Act. The exemption arises, however, not because the state has repealed the Sherman Act, ${ }^{192}$ but because, according to Parker's reading of

186. Id. at $596-98$.

187. The Court therefore did not reach the question of whether the standards would have been inconsistent had the light bulb distribution program been statewide.

188. 428 U.S. at 595.

189. Id. at 597 n.36 (quoting Gordon v. New York Stock Exchange, 422 U.S. 659 (1975)

(Stewart, J., concurring)).

190. 428 U.S. at 629.

191. Id. at 595. Mr. Justice Stewart in his dissent perceived that:

The "implied immunity" doctrine employed by this Court to reconcile the federal antitrust laws and federal regulatory statutes cannot, rationally, be put to the use for which the Court would employ it. That doctrine, a species of the basic rule that repeals by implication are disfavored, comes into play only when two arguably inconsistent federal statutes are involved. " Implied repeal'" of federal antitrust statutes by inconsistent state regulatory statutes is not only " "not favored," [428 U.S. at $598 \mathrm{n.37]}$ it is impossible.

Id. at 629 (emphasis in original). See notes 142-48 supra and accompanying text.

192. Indeed, the Court noted in Parker that states could not authorize violations of the Act or declare them legal. 317 U.S. at 351. 
the legislative history, Congress intended that in certain circumstances the jurisdiction of the federal government under the Sherman Act be replaced by that of the state. If the Cantor Court's reasoning is followed and the implied repeal test applied, any ancillary anticompetitive activities by a utility would not meet the standard. ${ }^{193}$ Such an approach focuses the inquiry too much on whether the activity is ancillary to the primary regulatory scheme rather than whether it effectuates an independent state policy. ${ }^{194}$

The Court does not separately discuss its third reason for finding that Congress did not intend to superimpose the antitrust laws on state regulated activities-that, even if such intent were assumed, enforcement of the antitrust laws in the light bulb market, an essentially unregulated area of the economy, would not be foreclosed. ${ }^{195}$ The conclusion that the distribution of light bulbs was essentially unregulated, however, seems to underlie the entire analysis of the second rationale. ${ }^{196}$ It was apparently this conclusion that influenced the Court's determination that the standards were not inconsistent and that an implied exemption was unnecessary. In application, then, the second rationale would be largely dependent on the resolution of the first - whether the state was sufficiently involved in the regulatory scheme.

The Court's treatment of these two rationales is disturbing. Mr. Justice Stewart, in dissent, described the Court as having fashioned "a new twopart test for determining whether state utility regulation creates immunity from the federal antitrust law." 197 The Court, however, spoke of "two quite different reasons" which "might support" a rule that "private conduct required by state law is exempt from the Sherman Act." 198 This language and the Court's separate discussion of the two rationales suggest that conduct which satisfied either one of the "tests" might be held exempt. Thus, the Court might determine that a particular activity need not be exempted to make the regulatory scheme work, for example, if it did not satisfy the second test, but involved such dominant participation by the state that it would be unjust to hold the private party liable. On the other hand, the

193. "For . . . if the federal antitrust laws should be construed to outlaw [Detroit Edison's] light bulb exchange program, there is no reason to believe that Michigan's regulation of its electric utilities will no longer be able to function effectively." $428 \mathrm{U}$.S. at 598 .

194. For example, if the light bulb exchange program had been adopted statewide, see note 187 supra, after due consideration and a determination that the most efficacious means of distribution was through the public utilities, under the Court's view the program would not be exempt since it would not be necessary to the primary regulatory scheme, the distribution of electricity.

195. 428 U.S. at 595.

196. See notes 188-94 supra and accompanying text.

197. 428 U.S. at 625.

198. Id. at 592 . 
Court's use of assumptions ${ }^{199}$ and inconclusive language ${ }^{200}$ suggests that the Court might not apply these rationales in a future case, but instead might impose a stricter standard. ${ }^{201}$

The extent to which the two rationales constitute tests deterinining the scope of the state action exemption is even less certain in light of the differences of opinion between the plurality and the Chief Justice as to the meaning of Parker. The plurality interpreted Parker as applying only to actions by the state or its officials or agents, ${ }^{202}$ and described Cantor as raising the issue of whether Parker should be "extended" to cover private action approved by a state and required to be continued while such approval was in effect. ${ }^{203}$ The Chief Justice disagreed that Parker could be linited to suits against state officials. He also considered such a reading of Parker unnecessary to the result in Cantor: Parker did not address the situation where the state, in addition to regulating a utility's exercise of natural monopoly. powers, also purported, "without any independent regulatory purpose, to control the utility's activities in separate, competitive markets." $204 \mathrm{He}$ concurred, however, in the plurality's determination that Michigan's policy towards the light bulb exchange program was neutral, noting that to base a state action exemption on Michigan's "undifferentiated sanction of this ancillary practice" would not serve any state or federal policy. ${ }^{205}$ If the state's involveinent were more than an undifferentiated sanction of an ancillary practice in a separate competitive market, the Chief Justice would surely find a state action exemption more readily than the plurality since to do so would not require an extension of his interpretation of Parker.

199. One commentator has described the Court's form of argument as assuming "without deciding the merits of issues whose relative significance was left unstated . . . "The Supreme Court, 1975 Term, supra note 79, at 234.

200. For example, the Court noted that "even though there may be cases in which the State's participation in a decision is so dominant that it would be unfair to hold a private party responsible for his conduct implementing it," Cantor presented no such unfairness. 428 U.S. at 594-95 (emphasis added). Similarly, the Court stated:

Therefore, assuming that there are situations in which the existence of state regulation should give rise to an implied exemption, the standards for ascertaining the existence and scope of such an exemption surely must be at least as severe as those applied to federal regulatory legislation.

Id. at 596-97 (emphasis added).

201. In fact a future Court might either (1) note that the Cantor Court did not affirmatively endorse any test governing the scope of the state action exemption and proceed to disavow the relevance of standards that were discussed; or (2) note that Cantor left open the possibility of denying an exemption to even those programs that met the tests it did articulate and proceed to add new ones.

The Supreme Court, 1975 Term, supra note 79, at $236 \mathrm{n.32}$.

202. 428 U.S. at 591.

203. Id. at 582 .

204. Id. at 604 .

205. Id. at 604-05. 


\section{CONCLUSION}

Mr. Justice Blackmun, in his concurring opinion in Cantor, suggested that the jurisdictional approach of Parker be replaced by a rule of reason, "taking it as a general proposition that state-sanctioned anticompetitive activity must fall like any other if its potential harms outweigh its benefits," with the "fact of state sanction figuring powerfully in the calculus of harm and benefit." ${ }^{206}$ The remaining justices declined to adopt his approach, though the interpretation which the plurality gave the Parker decision would severely limit its applicability. ${ }^{207}$ The dissent, in contrast, expressed the belief that '[t]he 'state action' doctrine of Parker v. Brown, as clarified by Goldfarb, represents the best possible accommodation of [the limiting intent of Congress in passing the Sherman Act] and the post-1890 judicial expansion of the jurisdictional reach of the Sherman Act." ${ }^{208}$ Whether the state action doctrine after Goldfarb was, as the dissent suggested, effectively "perform[ing] the salutary function of isolating those areas of state regulation where the State's sovereign interest is, by the State's own judgment, at its strongest, and limit[ing] the exemption to those areas," 209 is questionable. The inconsistent approaches taken by the lower courts in examining the factors relevant to a finding that Parker was applicable indicate that some further clarification of the doctrine was necessary. The solution proposed by the Court in Cantor, however, hardly seems the best one ${ }^{210}$ If the two reasons for holding private conduct required by the state immune from the antitrust laws are in fact to be employed as standards for determining the scope of the state action exemption, they will create difficulties. The first would require a court not only to ascertain the degree of state involvement in the challenged activity, but also to determine if holding the private party liable for such activity would be fair. ${ }^{211}$ The standards by which fairness is to be measured were not indicated and the addition of such an imprecise element to an already difficult inquiry seems unnecessary. The second would require a court to determine if Congress intended the antitrust

206. Id. at 610-11. Such a proposition is not novel. See notes 142-48 supra and accompanying text.

207. 428 U.S. at 589-91. The dissent noted that:

[I]f Parker v. Brown . . . could be circumvented by the simple expedient of suing the private party against whom the State's anticompetitive command runs, then that holding would become an empty formalism, standing for little more than the proposition that Porter Brown sued the wrong parties.

Id. at 616 n.4. See notes $164-66$ supra and accompanying text.

208. 428 U.S. at 637.

209. Id.

210. One district court has perceived, not too surprisingly, that after Cantor, "[t]he precise scope of the state action exemption is not entirely clear." Surety Title Ins. Agency, Inc. v. Virginia State Bar, 431 F. Supp. 298, 305 (E.D. Va. 1977).

211. 428 U.S. at 592-95. See notes 169-78 supra and accompanying text. 
laws to apply to an area of the economy regulated by the state, basing this inquiry on whether the private party would thereby have to satisfy inconsistent standards and whether the regulatory provisions are necessary to effective functioning of the regulatory act. ${ }^{212}$ The difficulty in determining congressional intent is illustrated by the Parker doctrine itself, and the adoption without refinement of the implied repeal doctrine developed in cases involving federal regulatory agencies ignores the principles of federalism emphasized by the Parker Court. ${ }^{213}$

If the Court was unwilling to adopt a straightforward balancing test such as that suggested by Mr. Justice Blackmun, it would have been preferable to adopt an approach focusing on elements considered important by the lower courts-the intent of the state to restrict competition and the degree of state involvement. If state intent took the form of express statutory authorization, the activity would be protected. If state intent were expressed by a state agency, the activity would be protected if it fell within the scope of the agency's authority. If no state intent could be determined, active state control, supervision or involvement in the activity would imply such an intent, and the activity would be protected. In each instance, the court would refuse to apply the Parker doctrine unless it felt the activity could reasonably be construed to reflect the considered judgment of the state or its authorized agents or it determined that Congress did not intend the antitrust laws to apply to such activity. Such an approach would in fact serve to limit the application of the state action exemption to those cases where the state's interest is strong, unlike the undifferentiated sanction without any independent regulatory purpose in Cantor. ${ }^{214}$ Such an approach would also allow the state itself to determine when the public interest could best be served by anticompetitive measures, thus avoiding "the selective interdiction of those anticompetitive state regulatory measures that are deemed not 'central' to the limited range of regulatory goals considered 'imperative' by the federal judiciary."215

212. 428 U.S. at 595-98. See notes $179-89$ supra and accompanying text.

213. See text accompanying notes 24-27 supra.

214. 428 U.S. at 605 (Burger, C.J., concurring).

215. Id. at 640 (Stewart, J., joined by Powell \& Rehnquist, J.J., dissenting). See note 178 supra. 